\title{
Improved GOMOS/Envisat ozone retrievals in the upper troposphere and the lower stratosphere
}

\author{
Viktoria F. Sofieva ${ }^{1}$, Iolanda Ialongo ${ }^{1}$, Janne Hakkarainen ${ }^{1}$, Erkki Kyrölä ${ }^{1}$, Johanna Tamminen ${ }^{1}$, Marko Laine ${ }^{1}$, \\ Daan Hubert ${ }^{2}$, Alain Hauchecorne ${ }^{3}$, Francis Dalaudier ${ }^{3}$, Jean-Loup Bertaux ${ }^{3}$, Didier Fussen ${ }^{2}$, Laurent Blanot ${ }^{4}$, \\ Gilbert Barrot ${ }^{4}$, and Angelika Dehn ${ }^{5}$ \\ ${ }^{1}$ Finnish Meteorological Institute, Helsinki, 00101, Finland \\ ${ }^{2}$ Royal Belgian Institute for Space Aeronomy (BIRA-IASB), Brussels, Belgium \\ ${ }^{3}$ Université Versailles St-Quentin, UPMC University Paris 06, CNRS/INSU, LATMOS-IPSL, 78280 Guyancourt, France \\ ${ }^{4}$ ACRI-ST, Sophia Antipolis, France \\ ${ }^{5}$ ESA/ESRIN, Frascati, Italy
}

Correspondence to: Viktoria F. Sofieva (viktoria.sofieva@ fmi.fi)

Received: 1 July 2016 - Published in Atmos. Meas. Tech. Discuss.: 24 August 2016

Revised: 25 November 2016 - Accepted: 16 December 2016 - Published: 20 January 2017

\begin{abstract}
Global Ozone Monitoring by Occultation of Stars (GOMOS) on board Envisat has performed about 440000 nighttime occultations during 2002-2012. Selfcalibrating measurement principle, good vertical resolution, excellent pointing accuracy, and the wide vertical range from the troposphere up to the lower thermosphere make GOMOS profiles interesting for different analyses.
\end{abstract}

The GOMOS ozone data are of high quality in the stratosphere and the mesosphere, but the current operational retrieval algorithm (IPF v6) is not optimized for retrievals in the upper troposphere-lower stratosphere (UTLS). In particular, validation of GOMOS profiles against ozonesonde data has revealed a substantial positive bias (up to $100 \%$ ) in the UTLS region. The retrievals in the UTLS are challenging because of low signal-to-noise ratio and the presence of clouds.

In this work, we discuss the reasons for the systematic uncertainties in the UTLS with the IPF v6 algorithm or its modifications based on simultaneous retrievals of several constituents using the full visible wavelength range. The main reason is high sensitivity of the UTLS retrieval algorithms to an assumed aerosol extinction model.

We have developed a new ozone profile inversion algorithm for GOMOS data (ALGOM2s version 1.0), which is optimized in the UTLS and uses IPF v6 advantages in the middle atmosphere. The ozone retrievals in the whole altitude range from the troposphere to the lower thermosphere are performed in two steps, as in the operational algorithm: spectral inversion followed by the vertical inversion. The spectral inversion is enhanced by using a DOAS-type method at visible wavelengths for the UTLS region. This method uses minimal assumptions about the atmospheric profiles. The vertical inversion is performed as in IPF v6 with the Tikhonov-type regularization according to the target resolution.

The validation of new retrieved ozone profiles with ozonesondes shows a dramatic reduction of GOMOS ozone biases in the UTLS. The new GOMOS ozone profiles are also in a very good agreement with measurements by MIPAS, ACE-FTS, and OSIRIS satellite instruments in the UTLS. It is also shown that the known geophysical phenomena in the UTLS ozone are well reproduced with the new GOMOS data.

\section{Introduction}

Monitoring ozone concentration in the UTLS (upper troposphere-lower stratosphere) is important, because the processes occurring in this region can strongly affect surface climate (Gettelman et al., 2011). Satellite sensors provide ozone profiles with high temporal and spatial resolution, necessary to resolve the strong variability in the UTLS. However, the UTLS region is difficult for exploration from space. Most nadir-looking instruments do not have a suffi- 
cient vertical resolution to resolve strong vertical gradients of interest, while limb-viewing instruments have difficulties because the atmosphere becomes nearly opaque at low altitudes. In addition, clouds are often sufficiently thick to stop many instruments from seeing through them.

This paper is dedicated to the validation of ozone profiles by the GOMOS (Global Ozone Monitoring by Occultation of Stars) instrument on board the Envisat satellite (2002-2012) with the specific focus on the UTLS region and to the optimization of GOMOS retrievals in the UTLS.

GOMOS is a stellar occultation instrument operating in UV-VIS-NIR wavelength region (Bertaux et al., 2010; Kyrölä et al., 2004). The atmospheric transmission spectra, which are obtained after dividing the stellar spectra observed through the Earth atmosphere by the reference spectrum, recorded above the atmosphere, contain spectral features of absorption and scattering by gases and particles. Ozone, $\mathrm{NO}_{2}, \mathrm{NO}_{3}$, and aerosol extinction are retrieved from the UV-VIS spectrometer data. Ozone can be retrieved up to $\sim 100 \mathrm{~km}$, while other species are detectable in the stratosphere and in the upper troposphere. The lowest altitude of the GOMOS measurements depends on stellar brightness and the presence of clouds (Tamminen et al., 2010); it is usually between 5 and $20 \mathrm{~km}$. The refractive attenuation and perturbations due to scintillation are removed from the GOMOS transmission spectra before the inversion (Kyrölä et al., 2010; Sofieva et al., 2009). The GOMOS data processing relies on the two-step inversion (Kyrölä et al., 2010). First, atmospheric transmission spectra from every tangent height are inverted to horizontal column densities (along the path of the light beam from the star) for gases and optical thickness for aerosols (spectral inversion). Then, for every constituent, the collection of the horizontal column densities at successive tangent heights is inverted to local density profiles (vertical inversion).

In the spectral inversion, horizontal column density of ozone, $\mathrm{NO}_{2}, \mathrm{NO}_{3}$, and aerosol extinction are retrieved simultaneously from UV-VIS spectrometer data in the wavelength range $250-675 \mathrm{~nm}$, for each tangent altitude (Kyrölä et al., 2010). The spectral inversion relies on the standard maximum likelihood method, which is enhanced by the socalled full-covariance-matrix inversion in order to take into account uncertainties due to incomplete scintillation correction (Sofieva et al., 2010). The vertical inversion is linear; it is performed for each constituent separately. The vertical inversion is stabilized by a Tikhonov-type regularization according to the target resolution (Sofieva et al., 2004; Tamminen et al., 2004).

Since the aerosol extinction spectrum is not known a priori, a polynomial of wavelength is used for the description of the aerosol extinction in the GOMOS retrievals. In the early version of GOMOS processor (Instrument Processor Facility (IPF) v4), a simplified aerosol extinction model proportional to $1 / \lambda$ ( $\lambda$ is wavelength) was used (Vanhellemont et al., 2005), while further developments (IPF v5 and IPF v6) used a second-degree polynomial model in $\lambda$ for the description of the aerosol extinction in GOMOS retrievals (Kyrölä et al., 2010; Vanhellemont et al., 2010). The study of Tamminen et al. (2010) has shown that the retrieval of GOMOS ozone profiles in the UTLS is highly sensitive to the aerosol model used. In particular, using higher-order (second- and thirdorder) polynomial aerosol models results in $\sim 30 \%$ larger ozone values in the UTLS and in the troposphere compared to the lower-order model (zero or first order).

The vertical resolution (including the smoothing properties of the inversion) of GOMOS ozone profiles is $2 \mathrm{~km}$ below $30 \mathrm{~km}$ and $3 \mathrm{~km}$ above $40 \mathrm{~km}$; it is the same for all occultations (Kyrölä et al., 2010; Sofieva et al., 2004; Tamminen et al., 2010). The stellar flux recorded by GOMOS, and thus signal-to-noise ratio and uncertainty of retrieved profiles, depends on stellar magnitude and spectral class. The estimated random uncertainty of GOMOS ozone profiles is $0.5-5 \%$ in the stratosphere and $1-10 \%$ in the mesosphere and lower thermosphere. Validation of the uncertainty estimates for ozone profiles in the stratosphere has shown that they are realistic except for dim stars (Sofieva et al., 2014a).

A dedicated validation of GOMOS profiles in the UTLS region has not been performed so far, although some results can be found in the extensive validation of GOMOS ozone profiles focused on the stratosphere. For IPF v4, Meijer et al. (2004) reported a positive bias $\sim 20 \%$ in tropical UTLS in comparisons with ozonesondes. In comparisons with ozonesondes at two polar stations, Tamminen et al. (2006) found $\sim 10 \%$ bias for Sodankylä $\left(67.4^{\circ} \mathrm{N}\right.$, $\left.23.6^{\circ} \mathrm{E}\right)$ and over $20 \%$ negative bias for Marambio $\left(64.3^{\circ} \mathrm{S}\right.$, $56.7^{\circ} \mathrm{W}$ ), for altitudes below $15 \mathrm{~km}$. For GOMOS ozone profiles processed with IPF v5, van Gijsel et al. (2010) have performed an analysis analogous to Meijer et al. (2004) but on a significantly larger dataset and found large GOMOS positive bias, over $40 \%$, in the tropical UTLS and below. This conclusion is in full agreement with the validation work of Mze et al. (2010) using ozone soundings from eight SHADOZ stations. The validation studies performed so far (which are also focused mainly on the stratospheric ozone) indicate, however, the presence of large GOMOS ozone bias in UTLS also in IPF v6 data. For example, Adams et al. (2014) reported over $20 \%$ positive GOMOS bias in UTLS in comparisons with OSIRIS/Odin v.5.0x profiles, which are of good quality in the UTLS (e.g., Cooper et al., 2011). Hubert et al. (2016) performed validation of GOMOS v.6 profiles with ozonesondes and reported a large positive ozone bias in the UTLS and the troposphere nearly everywhere except at polar high latitudes (only wintertime measurements are available for these locations). Large positive GOMOS ozone biases in UTLS are also observed in data agreement tables created for the HARMOZ dataset (Sofieva et al., 2013), which consists of user-friendly vertically gridded ozone profiles from six limb-viewing instruments (GOMOS, MIPAS, SCIAMACHY, OSIRIS, SMR and ACE-FTS). 
The operational GOMOS retrieval algorithm is optimized mainly for the stratosphere and the mesosphere (Kyrölä et al., 2010; Sofieva et al., 2010) but not for retrievals in the UTLS. This paper presents the results of studies aimed at optimization of GOMOS retrievals in the UTLS region. These studies have been performed in the framework of the European Space Agency (ESA) project ALGOM (GOMOS Level 2 evolution studies). The paper is organized as follows. First, in Sect. 2, we present the validation of GOMOS IPF v6 ozone profiles using ozonesonde data, which has been performed in the framework of the ESA DRAGON-3 and Ozone_cci projects, with a focus on the UTLS. Section 3 is dedicated to the discussion on sensitivity of GOMOS retrievals in the UTLS and the reason for large positive bias of IPF v6 ozone data. Section 4 is dedicated to the description of the new retrieval algorithm in the UTLS. In Sects. 5 and 6, extensive validation and geophysical assessment of the GOMOS ozone data processed with the FMI scientific processor is presented. A summary (Sect. 7) concludes the paper.

\section{Validation of IPF v6 ozone profiles with NDACC ozonesonde data}

\subsection{Data and methodology}

GOMOS IPF v6 nighttime ozone profiles (with solar zenith angles at tangent point larger than $105^{\circ}$ ) from the full mission are used in this work. The GOMOS data have been screened for outliers according to the recommendations in the readme document (https://earth.esa.int/web/sppa/mission-performance/ esa-missions/envisat/gomos/products-and-algorithms/ products-information). The GOMOS IPF v6 GOMOS dataset in user-friendly format is available at the Ozone_cci web page (http://www.esa-ozone-cci.org, Sofieva et al., 2013). Hereafter, we refer to IPF v6 as "V6" for short.

For validation, we used ozonesonde data from the Network for the Detection of Atmospheric Composition Change (NDACC, http://www.ndacc.org), WMO's Global Atmospheric Watch (GAW, data distributed by the World Ozone and Ultraviolet Data Centre, http://www.woudc.org), and the Southern Hemisphere Additional Ozonesondes network (SHADOZ, http://croc.gsfc.nasa.gov/shadoz; Thompson et al., 2012). Overall, the ozone data from 72 ozonesonde stations are used in the analysis. This collection of ozonesonde data was used in Hubert et al. (2016). The detailed information about ozonesonde stations can be found in Hubert et al. (2016, Table 1). Figure 1 (top) shows locations of the ozonesonde stations included in the comparison.

We selected GOMOS and ozonesonde data separated less than $1000 \mathrm{~km}$ in ground distance and less than $12 \mathrm{~h}$ in time. In the case of multiple collocations, only the closest was considered. The number of collocated measurements in $20^{\circ}$ latitude zones from $90^{\circ} \mathrm{S}$ to $90^{\circ} \mathrm{N}$ is illustrated in Fig. 1 (bottom).
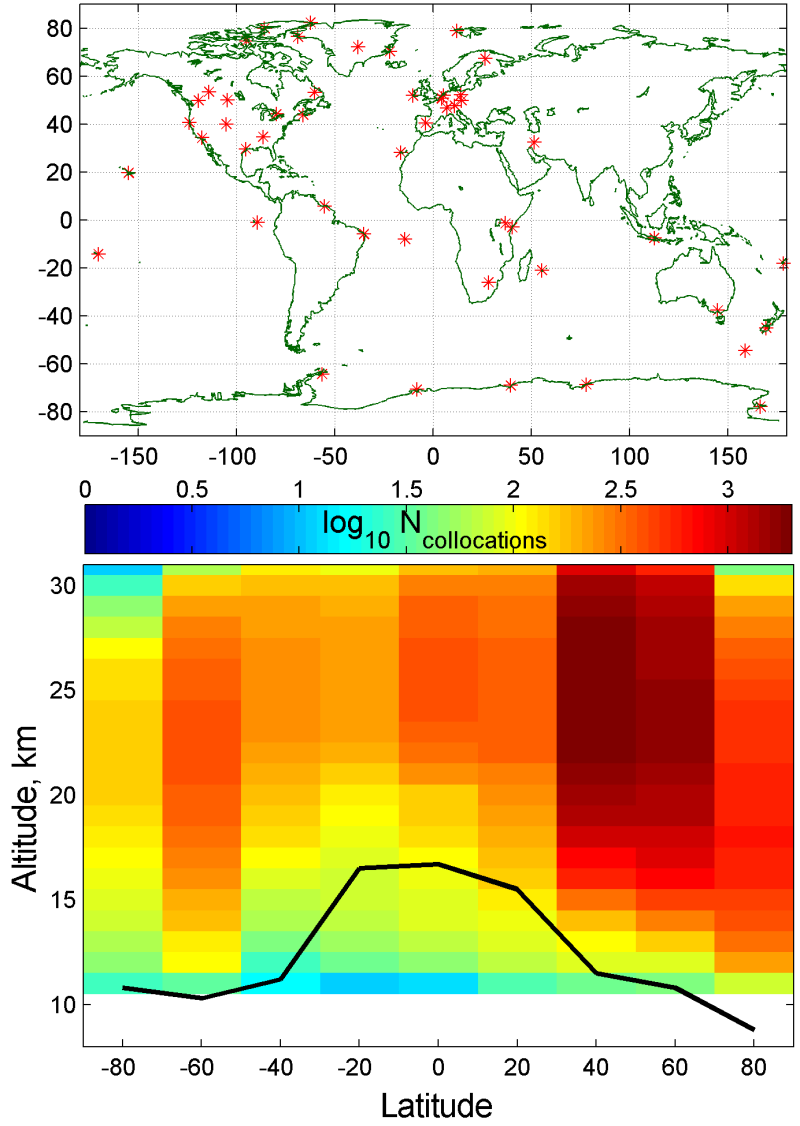

Figure 1. Top: locations of the ozonesonde stations considered in the comparison. Bottom: number of collocated measurements (logarithmic color scale) in $20^{\circ}$ latitude zones. The black line indicates the mean tropopause height.

The data coverage is the largest at Northern Hemisphere midlatitudes, and it is representative also in other latitude zones. The number of collocated measurements is smaller in the UTLS compared to the stratosphere.

GOMOS ozone profiles are interpolated to $1 \mathrm{~km}$ vertical grid. Ozonesonde data have been smoothed down to the vertical resolution of GOMOS ozone profiles and also interpolated to the same vertical grid. For every collocated pair of profile, the tropopause height is determined based on the WMO lapse-rate tropopause definition (WMO, 1957). The sonde temperature profiles are used for the tropopause detection. A detailed description of the tropopause height calculation can be found in, e.g., Sofieva et al. (2014b).

The relative differences $\delta$ between GOMOS ozone and the ozonesondes are computed as $\delta=(G-S) / S \times 100 \%$, where $G$ refers to GOMOS and $S$ to the ozonesonde ozone number density at each altitude. 

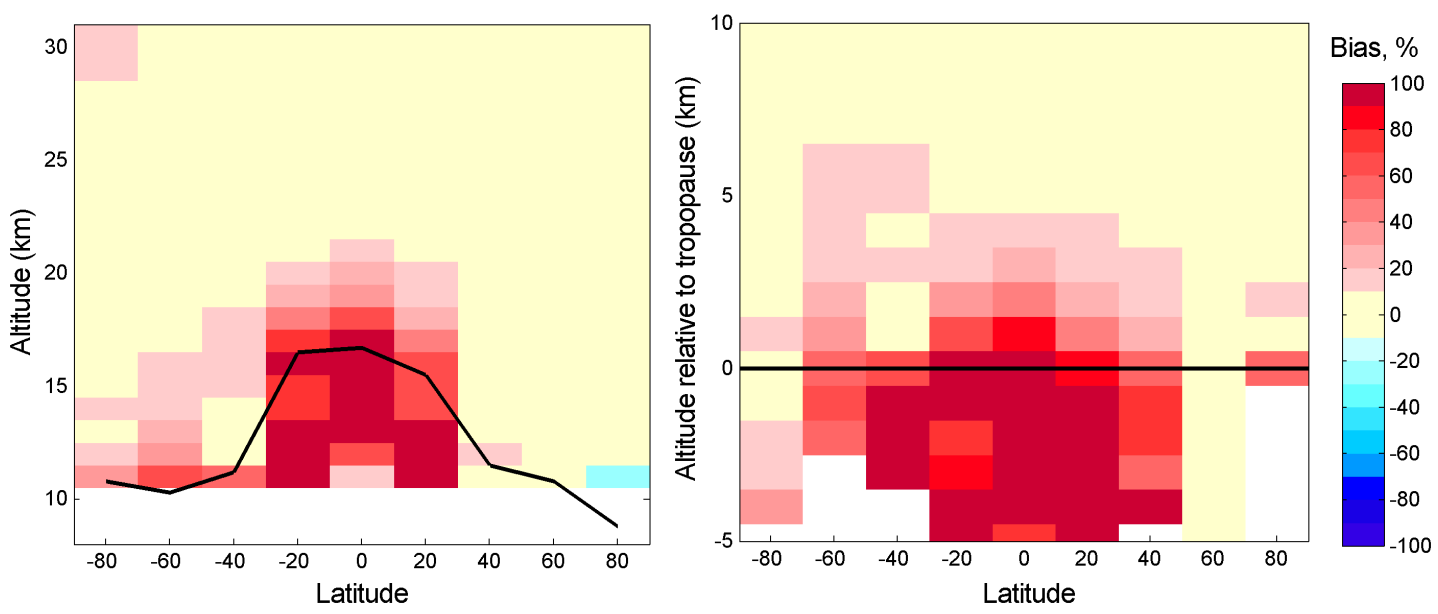

Figure 2. GOMOS V6 bias (median relative difference in \%) with respect to ozonesonde data as a function of altitude (left) and altitude relative to the tropopause (right). The black line indicates the average tropopause height.

\subsection{Validation results and discussion}

The validation presented in this section is focused on the UTLS region. Figure 2 shows the latitude dependence of the median relative difference between GOMOS V6 and ozonesonde profiles as a function of absolute altitude (left) and as a function of altitude relative to tropopause (right), averaged over the whole GOMOS period 2002-2011. We use median estimates due to their robustness to possible outliers.

As observed in Fig. 2, a large positive bias with respect to ozonesonde data is observed nearly everywhere in the UTLS except for Northern Hemisphere (NH) middle and high latitudes. The largest overestimation of UTLS ozone by GOMOS V6, over $100 \%$, is observed in the tropical region, where also most of the data below the tropopause are available. The mean difference between GOMOS and ozonesonde profiles is small in the middle stratosphere but becomes noticeable at altitudes $\sim 4 \mathrm{~km}$ above tropopause and rapidly increases with decreasing altitude. Near the tropopause, the biases achieve large values, which persist in the upper troposphere. At middle and high latitudes, biases in the UTLS are smaller, $\sim 10-40 \%$. At some locations (e.g., $50-70^{\circ} \mathrm{N}$ ), the bias with respect to ozonesonde data is even smaller than $10 \%$.

The best accuracy in GOMOS retrievals can be achieved using the brightest stars (the smallest noise). However, when only measurements from 12 brightest stars in the GOMOS catalog are taken into account (Fig. 3), the distribution of difference between GOMOS and the ozonesondes does not change essentially.

More illustrations of comparisons at individual stations can be found in Sect. 5 of the paper, where new GOMOS retrievals are compared with V6 retrievals and with ozonesonde profiles. All of them provide the same information as summarized in Fig. 2.

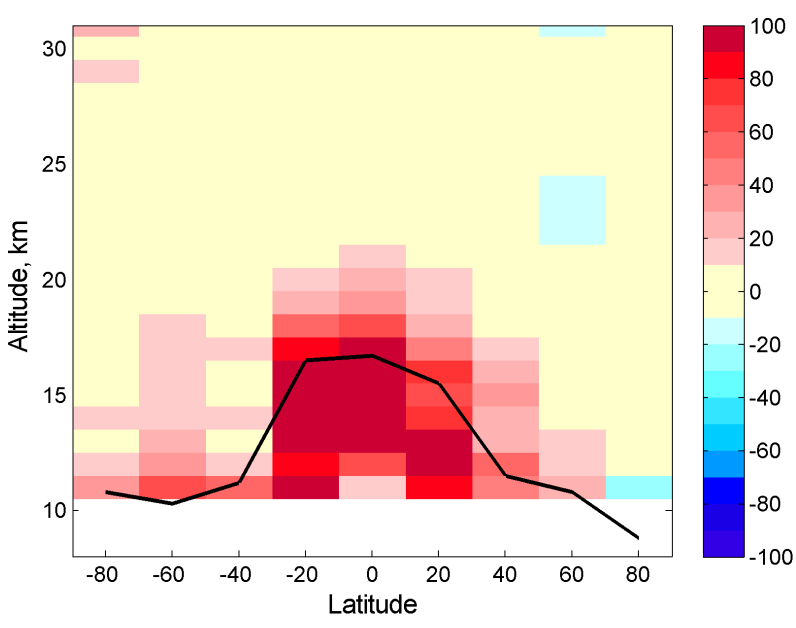

Figure 3. As Fig. 2 (left) but using data from 12 brightest stars in the GOMOS catalog.

The presented comparison of GOMOS ozone profiles with ozonesonde data, together with other analyses overviewed in the introduction, shows a consistent picture: GOMOS V6 ozone is overestimated in a large part of the UTLS. The largest difference was observed in the tropics (median relative difference up to $100 \%$ ). The observed positive bias does not show any dependence on the star brightness, making it impossible to select a subset of GOMOS dataset with realistic ozone profiles in the UTLS region. These validation results prompt us to develop an improved retrieval algorithm, which is discussed below. 

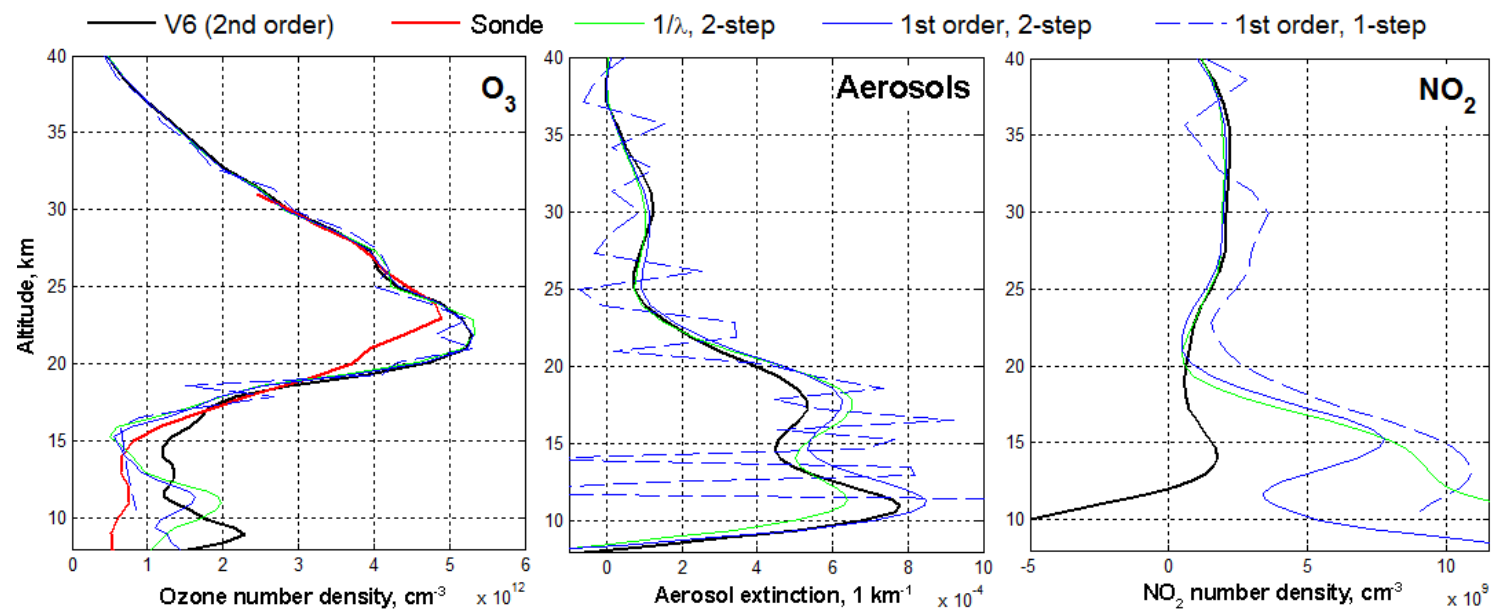

Figure 4. Sensitivity of ozone (left), aerosols (center), and $\mathrm{NO}_{2}$ (right) profile retrievals to the aerosol model used in inversion. The considered aerosol extinction models are $\sim 1 / \lambda$ model (green line), first-degree polynomial in $1 / \lambda$ (blue lines), and second-degree polynomial (V6, black line). The results for the first-degree polynomial model are shown for both two-step and one-step inversion. The ozonesonde profile is shown by the red line in the left panel.

\section{Identification of reasons for GOMOS V6 ozone biases in the UTLS}

The history of GOMOS algorithm development indicates that a possible reason for the large ozone bias in the V6 is the parameterization of aerosol extinction. We performed different sensitivity analyses with two scientific processors developed at FMI. The first one is GOMLAB, which is analogous to the official processor V6: it relies on the two-step inversion and has all specific features implemented in V6. GOMLAB has been used in several studies on development of GOMOS retrievals (e.g., Sofieva et al., 2010; Tamminen et al., 2010). In the second processor, which we refer to hereafter as the one-step retrieval algorithm, local density profiles are retrieved directly from transmission spectra, i.e., in one step (Hakkarainen et al., 2013). All performed analyses show that the retrieval of ozone, aerosols, and $\mathrm{NO}_{2}$ in the UTLS is very sensitive to the assumed model of aerosol extinction. This sensitivity was shown previously in Tamminen et al. (2010) and is also illustrated in Fig. 4 with examples of ozone, aerosols, and $\mathrm{NO}_{2}$ retrievals for one occultation of the very bright star Canopus R04078/S002 (10 December $2002 ; 30^{\circ} \mathrm{N}, 15^{\circ} \mathrm{W}$ ) collocated with ozone sounding at Izaña (time difference $11 \mathrm{~h} 37 \mathrm{~min}$, distance $223 \mathrm{~km}$ ). In Fig. 4, three aerosol extinction models are considered: the Angström law $\propto(1 / \lambda)$ (two-step retrievals with GOMLAB, green lines), first-degree polynomial model in $1 / \lambda$ (both onestep and two-step inversion, blue dashed and solid lines), and the second-degree polynomial model in $\lambda$ (two-step retrievals with V6, black lines). In the left panel of Fig. 4, the ozone profile measured by the collocated ozonesonde is shown by the red line. As observed in Fig. 4 (left), the V6 ozone profile has a large positive bias compared to ozonesonde. This bias is dramatically reduced when low-degree aerosol models are used (linear or $1 / \lambda$ ). The changes in the UTLS ozone are accompanied by the changes in aerosols and $\mathrm{NO}_{2}$. The retrieval results for one-step and two-step inversion are similar: the one-step profiles are noisier because less smoothing is applied in the inversion. With a stronger regularization, the one-step and two-step profiles look very similar.

The sensitivity of the GOMOS retrievals to the assumed aerosol model is large: ozone number density and aerosol extinction can change nearly by a factor of 2 , while changes in $\mathrm{NO}_{2}$ can be up to a few hundred percent. Such sensitivity is due to several reasons. First, the signal-to-noise ratio for stellar occultation measurements is relatively low in the UTLS. Second, GOMOS retrievals in the UTLS use the visible wavelengths $400-675 \mathrm{~nm}$, where the overall shape of ozone, aerosols, and $\mathrm{NO}_{2}$ cross sections can be approximated by a quadratic function (or a higher-degree polynomial). Therefore, if the absolute cross sections in the whole GOMOS VIS wavelength range are used, these constituents interfere in the retrievals. Third, the second-degree polynomial has a general deficiency for modeling aerosol extinction spectra: it gives more freedom to possible shapes of aerosol extinction spectra than can be observed for different composition of aerosol particles. Finally, we have to note that GOMOS spectra have perturbations due to residual scintillations (Sofieva et al., 2009), uncertainty of the dilution correction, and estimated extinction due to Rayleigh scattering. All these factors contribute to high sensitivity of GOMOS retrievals in the UTLS to the assumed model for aerosol extinction spectra.

This prompted us to develop a new ozone retrieval algorithm in the UTLS, which is less sensitive to aerosols. Using triplets in the Chappuis band - the method that is often used 
in retrievals from limb-scattering instruments (e.g., Degenstein et al., 2009; Flittner et al., 2000) - has allowed a simple and a robust inversion in the UTLS, which only assumes that the aerosol extinction is linear in a wavelength band of $\sim 150 \mathrm{~nm}$. Flittner et al. (2000) studied in details the performance of this DOAS-type algorithm under different aerosol loads and types and found that using triplets in the Chappuis band for ozone retrievals has a very low sensitivity to aerosols. Below we present the details of the application of the triplet method to GOMOS retrievals and extensive assessment of the retrieval results.

\section{GOMOS ozone inversion optimized for the UTLS (ALGOM2s)}

In this section, we describe a new GOMOS retrieval algorithm optimized for the UTLS. The proposed ozone retrieval algorithm in the whole GOMOS altitude range from the upper troposphere to the lower thermosphere inversion consists of the following steps:

1. retrievals of horizontal column density ozone profile in the UTLS using visible triplets

2. forming the resulting horizontal column density ozone profile in the whole GOMOS range by weighted combination of the V6 ozone profiles in the middle atmosphere and the new triplet ozone profile in the UTLS

3. performing the vertical inversion in the same way as in V6.

Below we describe each step in detail. Hereafter, we refer to the new processing method and the new GOMOS ozone dataset as "ALGOM2s v1.0". For more details on the IPF v6 algorithm, see the introduction and the corresponding references.

\subsection{Triplet inversion in the UTLS}

In order to reduce the sensitivity of ozone retrievals to aerosols, we use the triplet method. We use the same wavelengths as in the classical triplet method by Flittner et al. (2000): the reference wavelengths near 525 and $675 \mathrm{~nm}$ and absorbing wavelengths near $600 \mathrm{~nm}$. Since stars are relatively weak sources of light, several pixels are used for reference and absorbing wavelengths (Fig. 5). Using differential optical depth allows nearly canceling scintillation-dilution perturbations and a significant reduction of uncertainty due to Rayleigh scattering correction based on the ECMWF field. The Level $1 \mathrm{~b}$ transmission spectra $T_{\mathrm{L} 1 \mathrm{~b}}(\lambda)$ at a given tangent altitude can be expressed as

$T_{\mathrm{L} 1 \mathrm{~b}}(\lambda)=T_{\mathrm{ext}}(\lambda) \cdot T_{\mathrm{dil}}(\lambda) \cdot T_{\mathrm{sc}}(\lambda)$,

where $T_{\mathrm{dil}}(\lambda)$ and $T_{\mathrm{sc}}(\lambda)$ are transmittances due to dilution and scintillation, respectively.

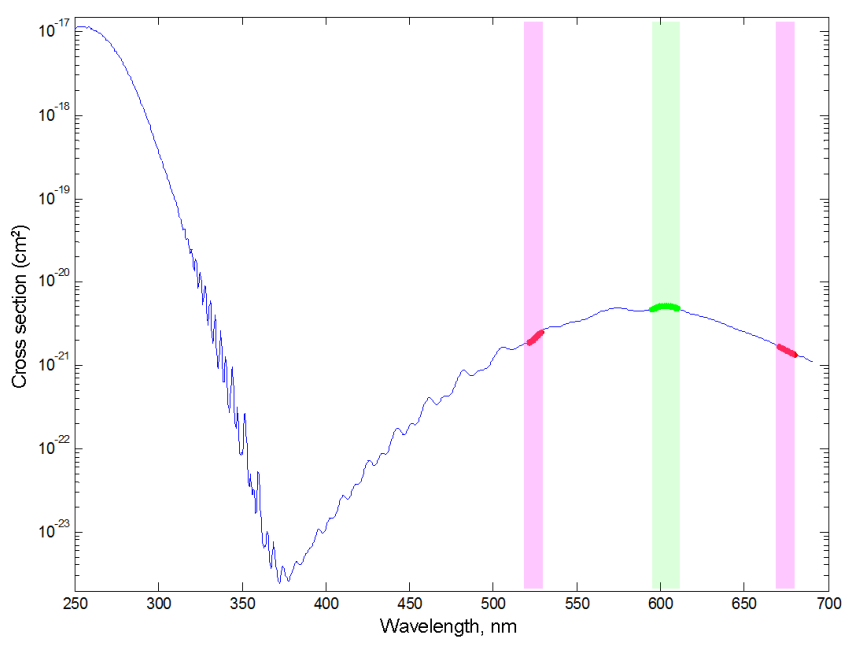

Figure 5. Reference (red, 521-529 and 670-680 nm) and absorbing (green, 592-612 nm) wavelengths.

For each altitude, the differential optical depth $\mathrm{d} \tau$ is computed as

$\mathrm{d} \tau=\tau\left(\lambda_{\mathrm{ab}}\right)-\frac{1}{2} \cdot\left(\left\langle\tau\left(\lambda_{r 1}\right)\right\rangle+\left\langle\tau\left(\lambda_{r 2}\right)\right\rangle\right)$,

where $\tau=-\ln \left(T_{\mathrm{L} 1 \mathrm{~b}}\right)$ is the optical depth, $\lambda_{\mathrm{ab}}$ is absorbing wavelength, and $\lambda_{r 1}$ and $\lambda_{r 2}$ are reference wavelengths. It has contributions due to ozone absorption, Rayleigh and aerosol scattering, and due to refractive effects. However, due to the selected wavelengths, ozone contribution to the differential optical depth strongly dominates. This is illustrated in Fig. 6, which compares the contributions of ozone absorption, Rayleigh scattering, and dilution (refractive attenuation) to the differential horizontal optical depth for the visible triplet 525, 602, and $675 \mathrm{~nm}$. This means that Level $1 \mathrm{~b}$ transmittances, without dilution and scintillation correction, can be used for the inversion from the visible triplets. The contribution from Rayleigh scattering to the differential optical depth is significantly smaller than that of ozone, but it can be as large as a few percent in the UTLS. Therefore, the Rayleigh optical depth is estimated (using the ECMWF field) and subtracted from the total optical depth data.

Computation of optical depth (taking logarithm) requires good signal-to-noise ratio. Only the pixels with the signal-tonoise ratio larger than 3 are used in the inversion. The uncertainty of the optical depth $\sigma_{\tau}$ is approximated as

$\sigma_{\tau}=\frac{\sigma_{T}}{T}$,

where $\sigma_{T}$ is uncertainty of transmittance $T$ (provided $\sigma_{T} \ll$ $T)$.

The retrievals of ozone horizontal column density (HCD) from Level $1 \mathrm{~b}$ data using visible triplet are performed only in the UTLS. That is, at altitudes below $z_{\mathrm{t}}+7 \mathrm{~km}, z_{\mathrm{t}}$ is the tropopause height. (In the middle and upper stratosphere, 


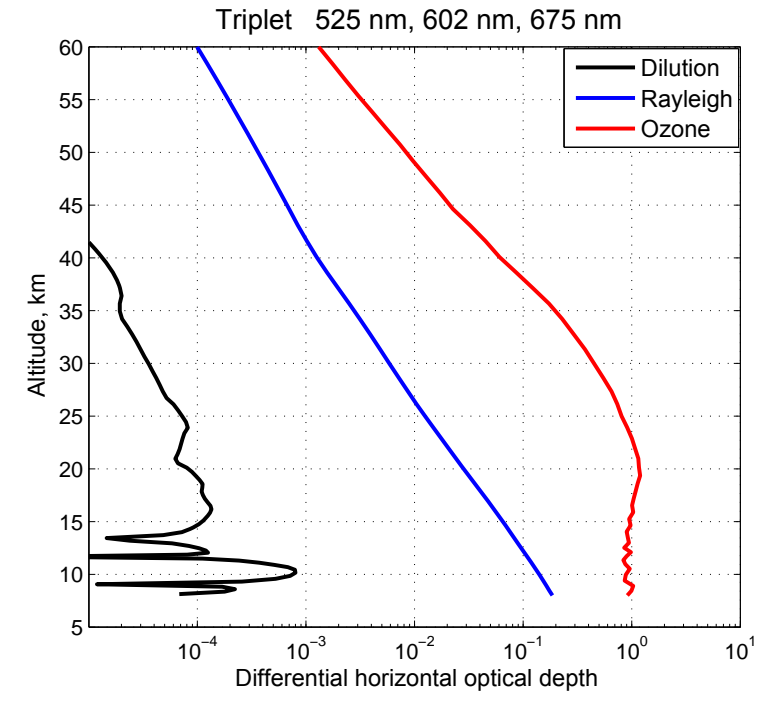

Figure 6. Differential horizontal optical depth for the visible triplet 525,602 , and $675 \mathrm{~nm}$ (see text for definition) due to ozone absorption, Rayleigh scattering, and dilution. The contributions are computed based on the occultation R04078/S002.

GOMOS ozone retrievals from the visible triplet only have large uncertainties.)

The average optical depth for reference channels $\left\langle\tau\left(\lambda_{r 1}\right)\right\rangle$ and $\left\langle\tau\left(\lambda_{r 2}\right)\right\rangle$ is used, and the triplet optical depth is computed for each channel at absorbing wavelengths from 592 to $612 \mathrm{~nm}$ according to Eq. (2). The uncertainties of the differential optical depth values (Eq. 2) are computed as

$\sigma_{\mathrm{d} \tau}^{2}=\sigma_{\tau}^{2}+\frac{1}{4} \sigma_{r 1}^{2}+\frac{1}{4} \sigma_{r 2}^{2}$,

where $\sigma_{\tau}$ is uncertainty in the absorbing channel and $\sigma_{r 1}$ and $\sigma_{r 2}$ are uncertainties of the average optical depth in the reference channels.

Ozone HCD is estimated for each pixel in absorbing channels $\mathrm{O}_{3}(\lambda)=\mathrm{d} \tau(\lambda) / D_{\text {cross }}(\lambda)$, where $D_{\text {cross }}(\lambda)$ is the differential cross sections corresponding to a triplet, and the weighted mean of these estimates $\overline{\mathrm{O}}_{3}$ is computed (with weights inversely proportional to uncertainties $\sigma_{\mathrm{O}_{3}}^{2}\left(\lambda_{i}\right)$ for individual absorbing channels). This is equivalent to the weighted least-squared estimates using all triplets. The associated uncertainty of the triplet $\mathrm{HCD} \overline{\mathrm{O}}_{3}$ is given by the uncertainty of the weighted mean:

$\sigma_{\overline{\mathrm{O}}_{3}}^{2}=\frac{1}{\sum_{i=1}^{N} \frac{1}{\sigma_{\mathrm{O}_{3}}^{2}\left(\lambda_{i}\right)}}$

provided that there is no systematic uncertainty in different values of $\mathrm{O}_{3}\left(\lambda_{i}\right)$. In Eq. (5), $N$ is number of absorbing channels. This assumption might be violated for the cases when the scintillation correction is not perfect. To take into account possible systematic uncertainties, the uncertainty of the triplet $\mathrm{HCD} \overline{\mathrm{O}}_{3}$ is estimated as

$$
\sigma_{\overline{\mathrm{O}}_{3}, \mathrm{corr}}^{2}=\frac{1}{\sum_{i=1}^{N} \frac{1}{\sigma_{\mathrm{O}_{3}}^{2}\left(\lambda_{i}\right)}} \times \frac{1}{(N-1)} \sum_{i=1}^{N} \frac{\left(\mathrm{O}_{3}\left(\lambda_{i}\right)-\overline{\mathrm{O}}_{3}\right)^{2}}{\sigma_{\mathrm{O}_{3}}^{2}\left(\lambda_{i}\right)} .
$$

In Eq. (6), the first factor is the uncertainty of the weighted mean, Eq. (5). The second factor in Eq. (6) takes into account variability between the different values of $\mathrm{O}_{3}\left(\lambda_{i}\right)$ that is not accounted for by the individual uncertainty estimates due to possible systematic uncertainties, which are different between the channels. For some samples, it may be that $\sigma_{\overline{\mathrm{O}}_{3}, \text { corr }}^{2}<\sigma_{\overline{\mathrm{O}}_{3}}^{2}$; in this case, $\sigma_{\overline{\mathrm{O}}_{3}}^{2}$ is taken as the uncertainty of the triplet horizontal column density.

\subsection{Combining V6 and triplet horizontal column densities}

The combining of V6 and triplet ozone profiles is performed in the UTLS (from $6 \mathrm{~km}$ above the tropopause until the lowermost altitude of an occultation).

The uncertainty of V6 is modified by adding a function increasing linearly from $0 \%$ at $\left(z_{\mathrm{t}}+6 \mathrm{~km}\right)$ to $20 \%$ at the tropopause height $z_{\mathrm{t}}$, with the saturation level of $20 \%$ below $z_{\mathrm{t}}$ (Fig. 7, left, labeled as "V6 systematic"). Such modification is assumed to characterize the systematic uncertainty of V6 ozone HCD due to uncertainty of the aerosol model. The combined ozone profile is the weighted mean of the V6 and triplet HCD profiles with the weights inversely proportional to uncertainties: modified V6 uncertainty for V6 profile and $\sigma_{\overline{\mathrm{O}}_{3}}$ (Eq. 6) for the triplet inversion (Fig. 7, center). As a result, above $\left(z_{\mathrm{t}}+6 \mathrm{~km}\right)$, ozone profile follows exactly V6 data. Below $\left(z_{\mathrm{t}}+6 \mathrm{~km}\right)$, the profiles are closer to the triplet inversion and practically coincide with the triplet inversion at the tropopause and below (Fig. 7, right).

If the lowest GOMOS altitude is above the tropopause, the triplet inversion is not performed and the profiles follow V6 data.

After combining the ozone horizontal column density profiles, the vertical inversion is performed in the same way as for V6.

\subsection{Examples of individual retrievals}

To highlight the changes in retrieval results compared to V6, the retrieved profiles for two occultations R09303/S002 and R04078/S002 are shown in Fig. 8. For comparison, collocated ozonesonde profiles are also shown in Fig. 8. As observed in Fig. 8, the retrieved ozone profiles with the new method are much closer to the ozonesonde profiles than those of V6.

It is worth noting that the results of ALGOM2s retrievals are very stable with respect to some variations in reference and absorbing wavelengths used in the triplet inversion. 

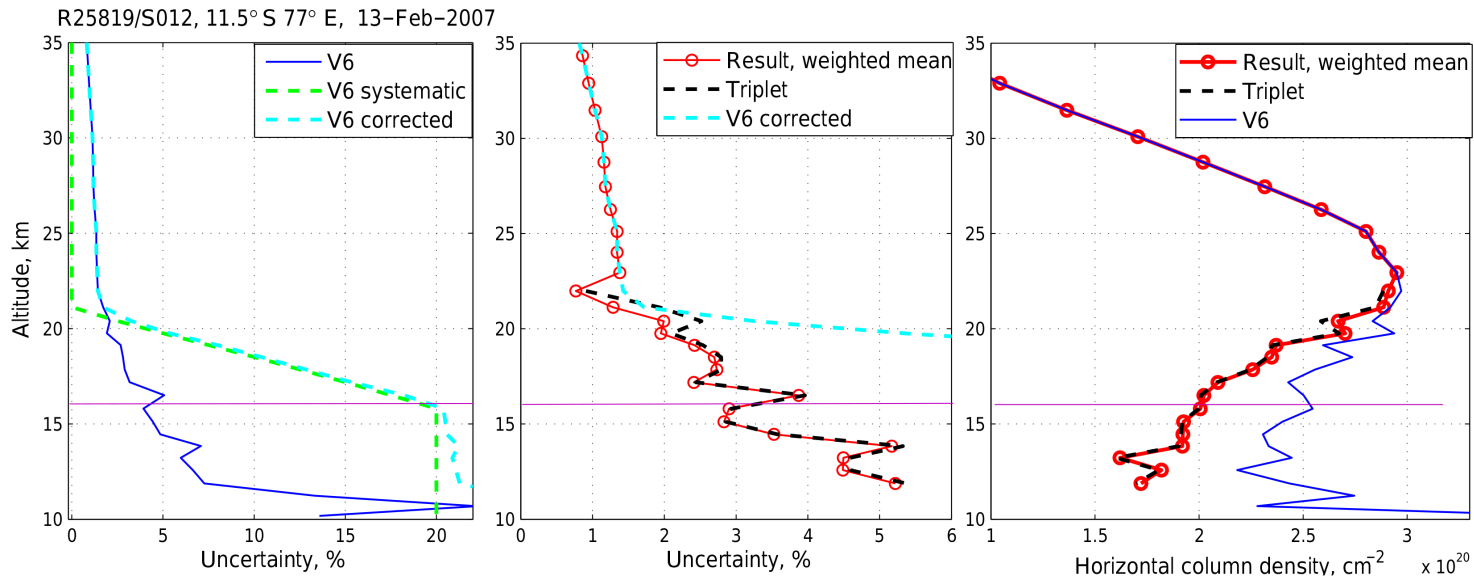

Figure 7. Illustration of combining triplet and V6 horizontal column density profiles using the data from occultation R25819/S012 (11.5 $5^{\circ}$, $77^{\circ} \mathrm{E} ; 13$ February 2007). Left: original uncertainty of V6 ozone HCD (blue line), systematic uncertainty (green), which is added quadratically to the original V6 uncertainty, and the resulting corrected V6 uncertainty (cyan). Center: V6 corrected uncertainty (cyan, as in the left panel), the uncertainty of the triplet inversion (black), and the resulting uncertainty of the weighted mean of V6 and triplet profiles (red). Right: V6 ozone HCD (blue), ozone HCD from triplet inversion (black), and the weighted mean of V6 and triplet profiles (red). The lapse-rate tropopause height is $\sim 16 \mathrm{~km}$ and is indicated my the magenta horizontal line.
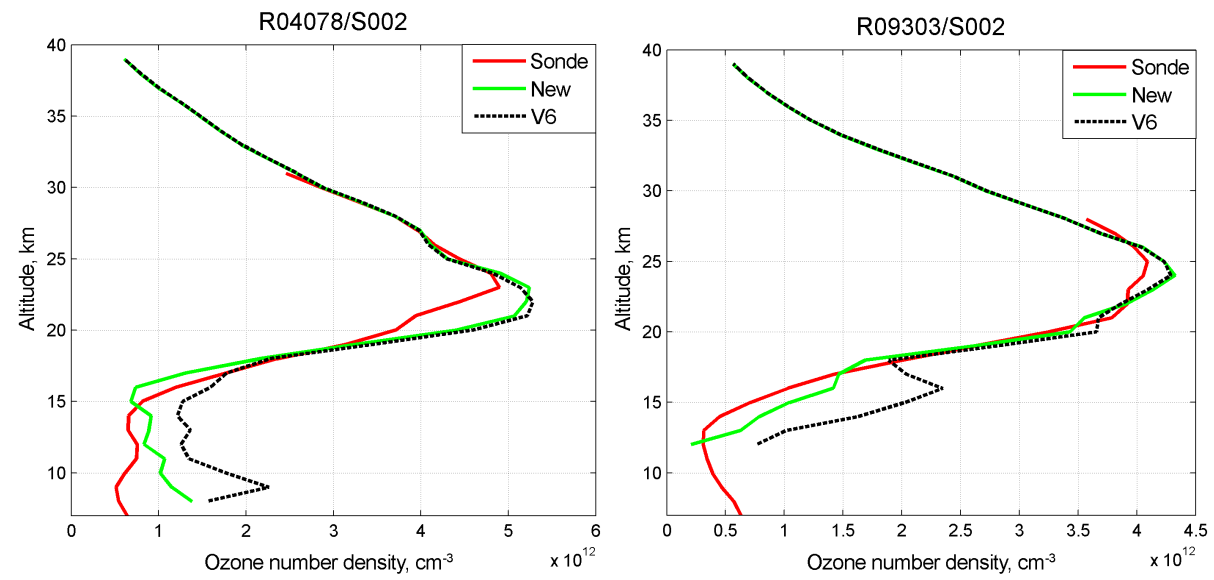

Figure 8. Ozone profiles for occultations R09303/S002 (left) and R04078/S002 (right) for the ALGOM2s retrievals ("new") compared to V6 and ozone sonde profiles at Izaña.

\section{Validation and intercomparison of the new retrievals: focus on the UTLS}

All the illustrations shown in the section are based on GOMOS dark-limb occultations (with solar zenith angle at tangent point larger than $105^{\circ}$ ), which were processed with the ALGOM2s algorithm. The collection of ozone data is the same as used in the Ozone_cci HARMOZ dataset (Sofieva et al., 2013) (validation of which is shown in Sect. 2 of this paper) with small changes of removal of occultations of a few stars with insufficient UV flux, which were not screened in the HARMOZ dataset. The applied screening of the GOMOS stars is based on UV signal-to-noise ratio; thus it filters the occultations, which might be affected significantly by the dark charge, automatically. The processed ozone data were screened for outliers according to recommendations written in GOMOS V6 disclaimer (outlier profiles are usually due to contamination by cosmic rays).

\section{Validation against ozonesondes}

For validation against ozonesondes, we used the same data as in validation of V6 dataset presented in Sect. 2.

Figures 9 and 10 show the results of the validation of ALGOM2s ozone profiles against NDACC ozonesondes for tropical and high-latitude stations, respectively. For comparison, the results for V6 ozone profiles are also shown. For tropical stations, the dramatic reduction of biases is observed. At polar stations, the ALGOM2s results are not worse than 

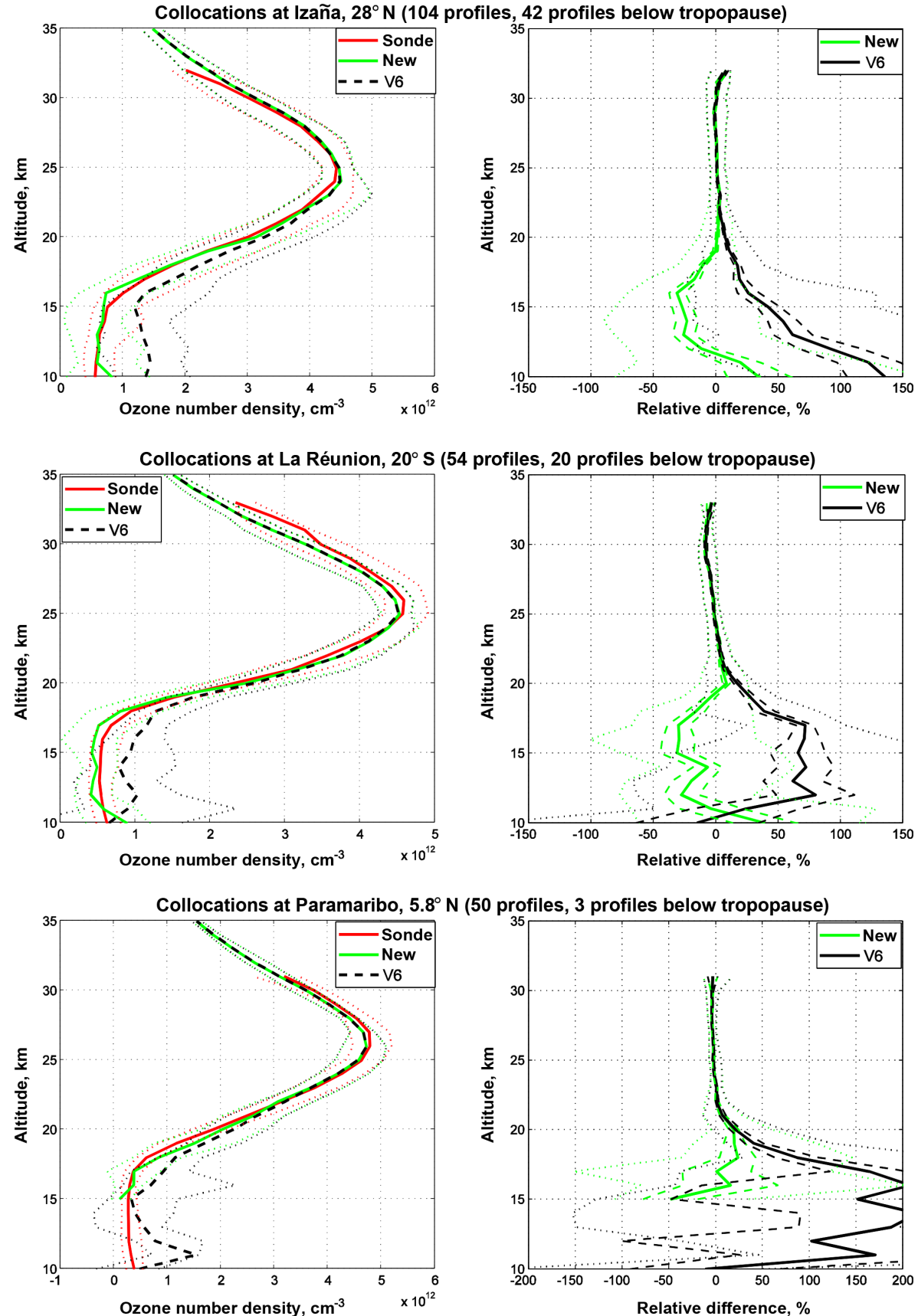

Figure 9. Statistics of comparison with ozonesondes at Izaña (top), Réunion (center) and Paramaribo (bottom). Left: median profiles (solid lines) and 16th and 84th percentiles (dotted lines) indicating the spread of relative differences. Right: solid lines indicate median of relative differences, dotted lines the 16th and 84th percentiles, and dashed lines indicate the standard error of the mean.

those of V6 (at polar stations, also V6 data have a small bias in the UTLS in comparisons with ozonesondes).

Figure 11 shows the global distribution of the median relative difference between GOMOS ALGOM2s and ozonesonde data as a function of absolute altitudes and relative to the tropopause altitudes, similar to that presented in Fig. 2 for V6 data. The dramatic reduction of biases in the tropical UTLS and troposphere is observed; the ALGOM2s profiles are nearly unbiased with respect to ozonesonde data. In the close vicinity to the tropical tropopause, ALGOM2s reports $\sim 20 \%$ less ozone than the collocated ozonesonde data. At SH middle and high latitudes, ALGOM2s biases with respect to ozone sonde data are also decreased. At 30$50^{\circ} \mathrm{N}$ (comparing right panels in Figs. 11 and 2), the bias 

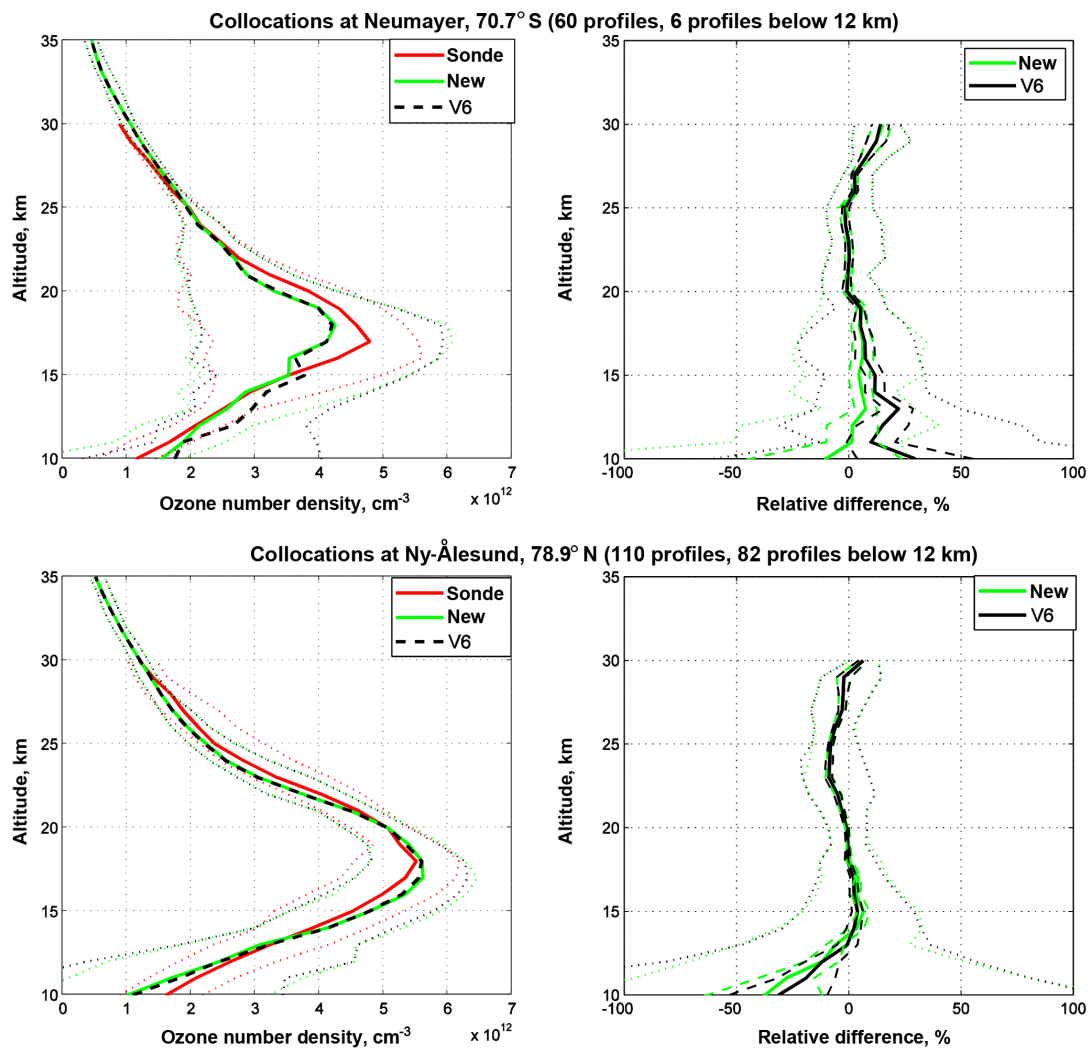

Figure 10. As Fig. 9 but for collocations at Neumayer (top) and Ny-Ålesund (bottom).
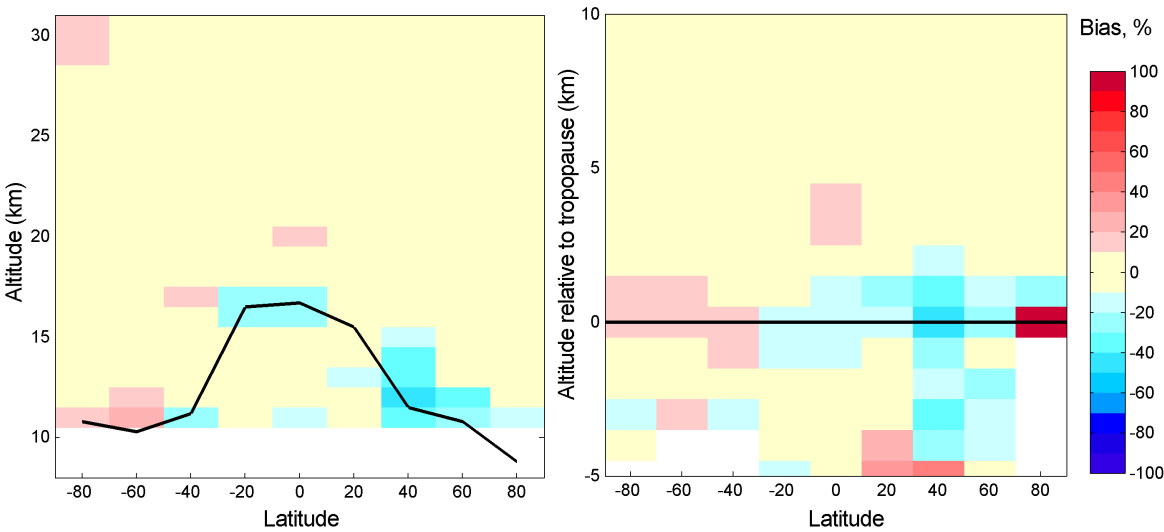

Figure 11. As Fig. 2 but for GOMOS ALGOM2s ozone profiles.

changes from $\sim+50 \%$ (V6) to $\sim-20 \%$ (ALGOM2s). At $50-70^{\circ} \mathrm{N}$, the bias changes from $<10 \%$ (V6) to $\sim-20 \%$ (ALGOM2s).

The global distribution of the spread of relative differences, which is computed as $0.5 \times\left(P_{84}-P_{16}\right)$, where $P_{84}$ and $P_{16}$ are 84 th and 16 th percentiles of the distribution, is shown in Fig. 12 in the tropopause-referenced representation. A reduction of the spread in the tropical UTLS is clearly observed for new ALGOM2s retrievals.

\section{Some geophysical illustrations in the UTLS using the ALGOM2s data}

As an illustration of a large dataset, the GOMOS ozone profiles in the equatorial region (latitudes $20^{\circ} \mathrm{S}-20^{\circ} \mathrm{N}$ ) in $2007-$ 2008 are compared with ozone profiles from other satellite instruments - MIPAS (von Clarmann et al., 2003, 2009), OSIRIS (Degenstein et al., 2009) and ACE-FTS (Bernath et al., 2005) - which have been already used in several scientific studies in the UTLS (Aschmann et al., 2014; von Clarmann 


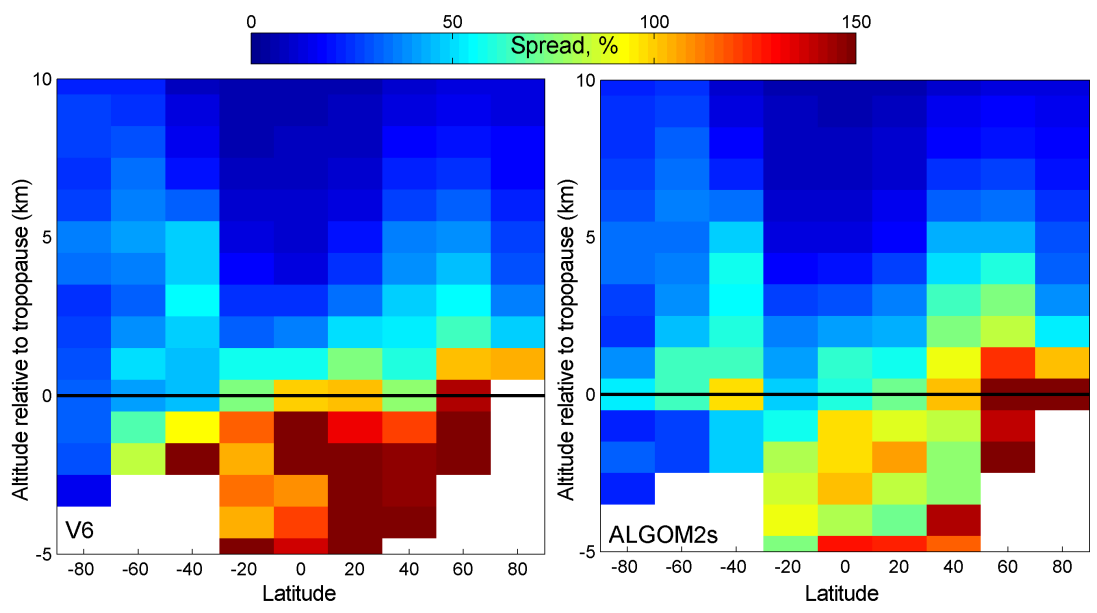

Figure 12. Spread in \% of relative differences with respect to ozonesonde profiles for GOMOS V6 (left) and GOMOS ALGOM2s retrievals (right).
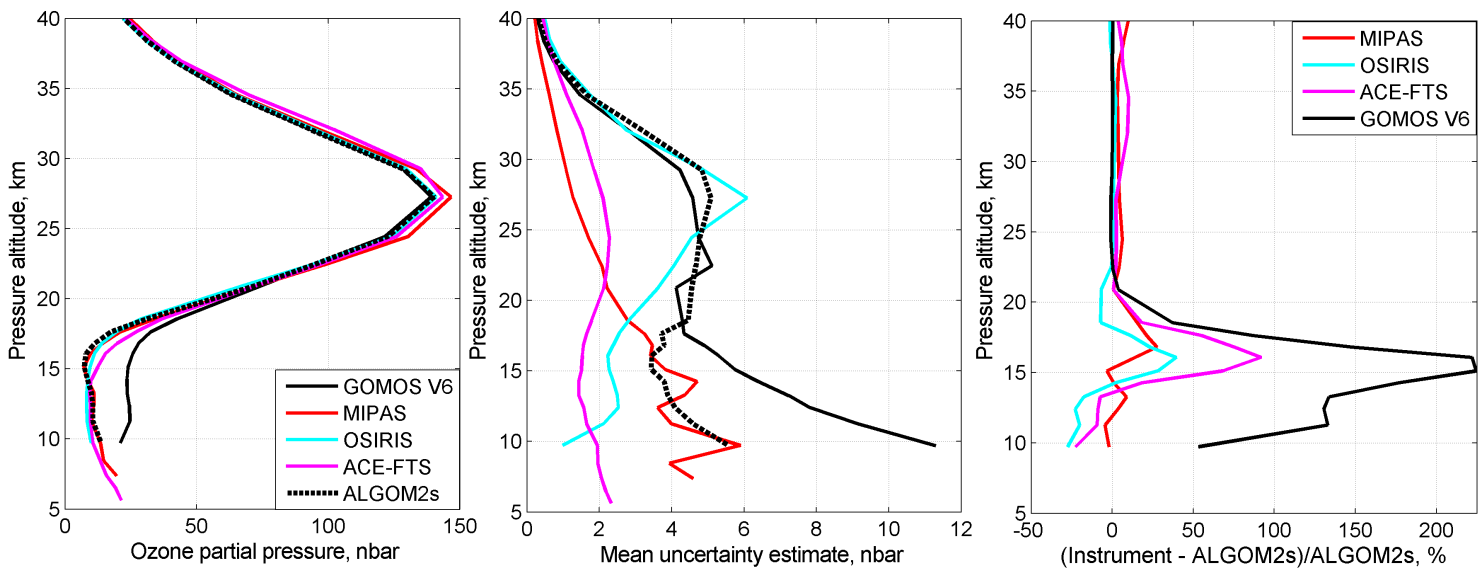

Figure 13. Left: mean ozone profiles at $20^{\circ} \mathrm{S}-20^{\circ} \mathrm{N}$ in $2007-2008$ for GOMOS V6, MIPAS, OSIRIS, ACE-FTS, and the ALGOM2s GOMOS processor. Center: mean ozone uncertainty estimates for each instrument in nbar. Right: mean relative difference of ozone profiles with respect to ALGOM2s (Instrument-ALGOM2s/ALGOM2s) in \%.

et al., 2007; Cooper et al., 2013; Kunze et al., 2010; Liu et al., 2009; Manney et al., 2011; Sioris et al., 2014). As observed in Fig. 13 (left), the GOMOS V6 ozone profiles are strongly biased in the tropical UTLS, while new GOMOS data are close to the profiles from other satellite instruments. A very good agreement of GOMOS and OSIRIS profiles in the middle stratosphere can be noticed in Fig. 13 (left and right panels). For the ALGOM2s retrievals, the mean profile is close to that of OSIRIS also in the UTLS. The ALGOM2s gives slightly smaller ozone in the vicinity of the tropical tropopause $(\sim 20-30 \%)$ compared to MIPAS and OSIRIS. This feature is also observed in comparisons with ozonesondes. The mean uncertainty of ALGOM2s ozone profiles is smaller in the UTLS than that of V6 data in absolute values (Fig. 13, center).

Seasonal variations and temporal evolution of ozone profiles in the UTLS are the subject of intensive research (e.g.,
Gettelman et al., 2010; Hegglin et al., 2010; Randel and Jensen, 2013; Sioris et al., 2014). Figure 14 shows the temporal evolution of ozone profiles in the equatorial region $\left(20^{\circ} \mathrm{S}-20^{\circ} \mathrm{N}\right)$ from OSIRIS and two versions of GOMOS data. The pronounced seasonal cycle associated with the variations in the tropopause height are clearly observed in all datasets. The ozone values in the troposphere for the ALGOM2s retrievals are closer to those of OSIRIS than V6 profiles. It should be noted that the coverage of the UTLS region by GOMOS data is limited due to applied screening by signal-to-noise ratio; thus the seasonal cycle is reproduced in GOMOS data with a significant sampling uncertainty.

The Asian summer monsoon (ASM) contains a strong anti-cyclonic vortex in the UTLS, spanning from Asia to the Middle East. The ASM has been recognized as a significant transport pathway for water vapor and pollutants to the stratosphere (e.g., Kunze et al., 2010; Park et al., 2007). 


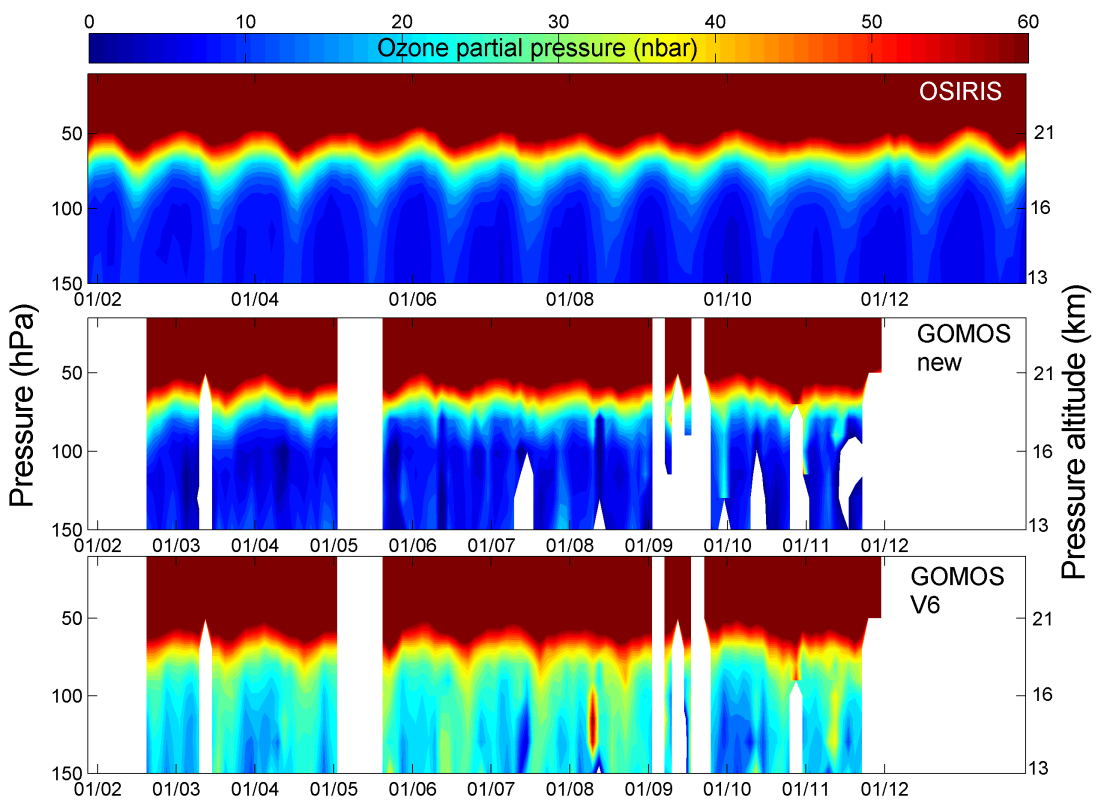

Figure 14. Time series of ozone partial pressure profiles in nbar at $20^{\circ} \mathrm{S}-20^{\circ} \mathrm{N}$ from OSIRIS (top), ALGOM2s retrievals (center, GOMOS "new"), and GOMOS V6 (bottom).
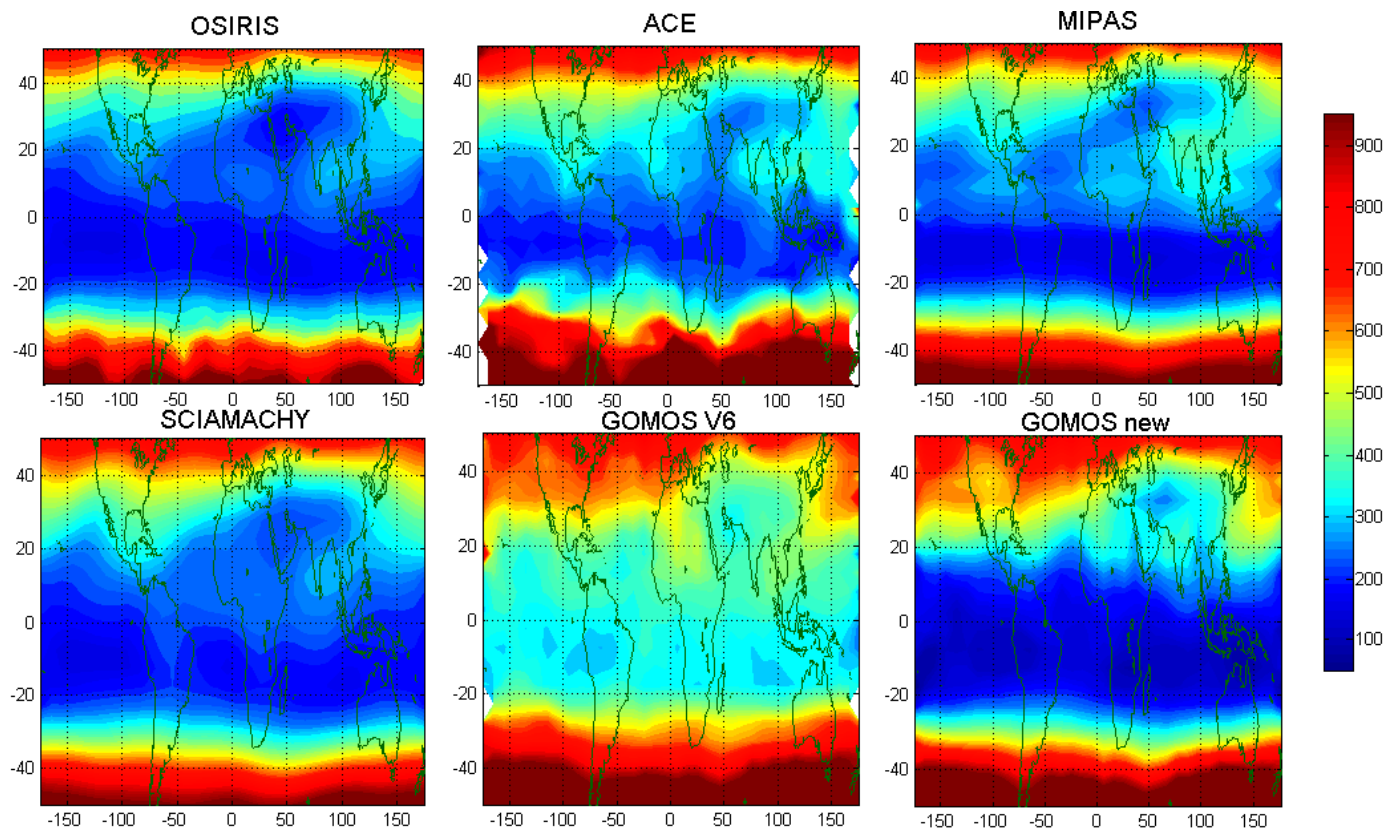

Figure 15. Mean ozone mixing ratio (ppb) at $100 \mathrm{hPa}$ in the summer season (June-August), as inferred from all available measurements by OSIRIS, ACE-FTS, MIPAS, SCIAMACHY, and GOMOS (V6 and ALGOM2s retrievals, "GOMOS new").

Figure 15 shows ozone distributions at $100 \mathrm{hPa}(\sim 16 \mathrm{~km})$ in June-August from OSIRIS, ACE-FTS, MIPAS, SCIAMACHY, and GOMOS measurements. To obtain these maps, all available data have been used. For GOMOS, the maps are shown for both V6 and ALGOM2s ("GOMOS new") retrievals. The low ozone values in Asia associated with the strong upward motion of tropospheric air are clearly seen in these distributions, and peculiar features of ozone associated with the ASM are very similar in all datasets displayed. For V6, the ozone UTLS data have a significant positive offset, but lower values associated with ASM are observed in V6 distribution as well. For new GOMOS retrievals, the distribution is very similar to those by other satellite instruments. 


\section{Summary and discussion}

Satellite data with a good quality in the UTLS are very important for the studies of the complex processes and longterm changes in the UTLS. The validation of GOMOS IPF v6 ozone profiles against ozonesonde data has shown a strong overestimation (median relative difference up to $100 \%$ ) of the ozone values by GOMOS IPF v6 in the UTLS. The largest difference was observed in the tropics. The observed positive bias does not show any dependence on the star brightness, thus making it impossible to select a subset of GOMOS ozone V6 data with realistic ozone profiles in the UTLS region.

The extensive sensitivity analyses have shown that the current GOMOS retrievals of ozone, aerosols, and $\mathrm{NO}_{2}$ are very sensitive to parameterization of aerosol extinction used in the inversion. In this paper, we have presented a new algorithm for GOMOS ozone retrievals in the UTLS by using the visible triplets.

Using relatively narrow wavelength bands in the triplet inversion allows avoiding the scintillation and dilution correction (allows using Level $1 \mathrm{~b}$ transmittances) and reducing uncertainty related to aerosol extinction spectral dependence and removal of Rayleigh scattering. The proposed inversion using visible triplets in the UTLS is stable with respect to small variations of reference and absorbing wavelengths.

For the proposed inversion (ALGOM2s), the ozone profiles follow V6 data in the middle atmosphere and follow the triplet ozone profiles in the UTLS and the troposphere. Such an approach seems to be advantageous for the ongoing Ozone_cci project (http://www.esa-ozone-cci.org/). GOMOS V6 ozone data have been extensively validated; they exhibit good quality and small biases with respect to groundbased measurements in the stratosphere (Adams et al., 2014; van Gijsel et al., 2010; Hubert et al., 2016; Laeng et al., 2014; Rahpoe et al., 2015). The ALGOM2s ozone data preserve all positive features of V6 in the stratosphere and have a significantly improved quality in the UTLS.

ALGOM2s ozone concentrations are on average lower and less noisy in the UTLS than the IPF v6 data. The ALGOM2s ozone profiles are in good agreement with ozone sondes and other satellite data having a good quality in the UTLS. The geophysical phenomena are seen by the GOMOS dataset, but the coverage of the UTLS data by GOMOS is limited.

In the current dataset, all occultations of stars with insufficient UV flux (cool or/and dim stars) are excluded due to their problems in the upper atmosphere and also in the UTLS due to the influence of dark current noise, which increases during the GOMOS mission (Tamminen et al., 2010). For climatologic studies, the application of a similar ozone inversion to averaged GOMOS transmittances, the approach used in Fussen et al. (2004, 2005, 2010) and Tétard et al. (2009), might provide a richer GOMOS climatologic dataset in the UTLS due to inclusion of more occultations and a less strict data filtering according to signal-to-noise ratio.

\section{Data availability}

The ALGOM2s ozone dataset is available at the ALGOM website (https://earth.esa.int/web/sppa/activities/ instrument-characterization-studies/algom/data-resources).

It will be also provided in the user-friendly Ozone_cci netcdf format (Sofieva et al., 2013), on both pressure and altitude grid; it is expected to replace the current GOMOS dataset used in the Ozone_cci project. It will be available at the Ozone_cci website (http://www.esa-ozone-cci.org/?q=node/161). Interested users can acquire all intermediate data products from the corresponding author.

Acknowledgement. The development of the GOMOS algorithms has been performed in the framework of the ESA project ALGOM. The validation against ozone sondes is supported by the ESA DRAGON-3 program and Ozone_cci project. The comparison with satellite measurements has been performed in the framework of the ESA Ozone_cci project. The FMI team acknowledges the support by the Academy of Finland (project INQUIRE). The correlative data from balloon-based ozonesonde used in this publication were obtained from the NDACC network (www.ndsc.ncep.noaa.gov), World Ozone and Ultraviolet Data Centre (http://www.woudc.org), and the Southern Hemisphere Additional Ozonesondes network (SHADOZ, http://croc.gsfc.nasa.gov/shadoz). We acknowledge the meticulous and sustained work of the PIs and staff at ozonesonde stations to acquire and maintain ozone profile data records of high quality. The authors thank OSIRIS, MIPAS, and ACE-FTS teams for providing the data. We thank the reviewers for their useful comments.

Edited by: M. Weber

Reviewed by: A. Rozanov and one anonymous referee

\section{References}

Adams, C., Bourassa, A. E., Sofieva, V., Froidevaux, L., McLinden, C. A., Hubert, D., Lambert, J.-C., Sioris, C. E., and Degenstein, D. A.: Assessment of Odin-OSIRIS ozone measurements from 2001 to the present using MLS, GOMOS, and ozonesondes, Atmos. Meas. Tech., 7, 49-64, doi:10.5194/amt-7-49-2014, 2014.

Aschmann, J., Burrows, J. P., Gebhardt, C., Rozanov, A., Hommel, R., Weber, M., and Thompson, A. M.: On the hiatus in the acceleration of tropical upwelling since the beginning of the 21 st century, Atmos. Chem. Phys., 14, 12803-12814, doi:10.5194/acp14-12803-2014, 2014.

Bernath, P. F., McElroy, C. T., Abrams, M. C., Boone, C. D., Butler, M., Camy-Peyret, C., Carleer, M., Clerbaux, C., Coheur, P.-F., Colin, R., DeCola, P., DeMazière, M., Drummond, J. R., Dufour, D., Evans, W. F. J., Fast, H., Fussen, D., Gilbert, K., Jennings, D. E., Llewellyn, E. J., Lowe, R. P., Mahieu, E., McConnell, J. C., McHugh, M., McLeod, S. D., Michaud, R., Midwinter, C., Nassar, R., Nichitiu, F., Nowlan, C., Rinsland, C. P., Rochon, Y. J., Rowlands, N., Semeniuk, K., Simon, P., Skelton, R., Sloan, J. J., Soucy, M.-A., Strong, K., Tremblay, P., Turnbull, D., Walker, K. 
A., Walkty, I., Wardle, D. A., Wehrle, V., Zander, R., and Zou, J.: Atmospheric Chemistry Experiment (ACE): Mission overview, Geophys. Res. Lett., 32, L15S01, doi:10.1029/2005GL022386, 2005.

Bertaux, J. L., Kyrölä, E., Fussen, D., Hauchecorne, A., Dalaudier, F., Sofieva, V., Tamminen, J., Vanhellemont, F., Fanton d'Andon, O., Barrot, G., Mangin, A., Blanot, L., Lebrun, J. C., Pérot, K., Fehr, T., Saavedra, L., Leppelmeier, G. W., and Fraisse, R.: Global ozone monitoring by occultation of stars: an overview of GOMOS measurements on ENVISAT, Atmos. Chem. Phys., 10, 12091-12148, doi:10.5194/acp-10-12091-2010, 2010.

Cooper, M., Martin, R. V, Sauvage, B., Boone, C. D., Walker, K. A., Bernath, P. F., McLinden, C. A., Degenstein, D. A., Volz-Thomas, A., and Wespes, C.: Evaluation of ACE-FTS and OSIRIS Satellite retrievals of ozone and nitric acid in the tropical upper troposphere: Application to ozone production efficiency, J. Geophys. Res.-Atmos., 116, D12306, doi:10.1029/2010JD015056, 2011.

Cooper, M. J., Martin, R. V, Livesey, N. J., Degenstein, D. A., and Walker, K. A.: Analysis of satellite remote sensing observations of low ozone events in the tropical upper troposphere and links with convection, Geophys. Res. Lett., 40, 3761-3765, doi:10.1002/grl.50717, 2013.

Degenstein, D. A., Bourassa, A. E., Roth, C. Z., and Llewellyn, E. J.: Limb scatter ozone retrieval from 10 to $60 \mathrm{~km}$ using a multiplicative algebraic reconstruction technique, Atmos. Chem. Phys., 9, 6521-6529, doi:10.5194/acp-9-6521-2009, 2009.

Flittner, D. E., Bhartia, P. K., and Herman, B. M.: $\mathrm{O}_{3}$ profiles retrieved from limb scatter measurements: Theory, Geophys. Res. Lett., 27, 2601-2604, doi:10.1029/1999GL011343, 2000.

Fussen, D., Vanhellemont, F., Bingen, C., Kyrola, E., Tamminen, J., Sofieva, V. F., Hassinen, S., Seppala, A., Verronen, P., Bertaux, J.-L., Hauchecorne, A., Dalaudier, F., Renard, J. B., Fraisse, R., D'Andon, O. F., Barrot, G., Mangin, A., Theodore, B., Guirlet, M., Koopman, R., Snoeij, P., and Saavedra, L.: Global measurement of the mesospheric sodium layer by the star occultation instrument GOMOS, Geophys. Res. Lett., 31, L24110, doi:10.1029/2004GL021618, 2004.

Fussen, D., Vanhellemont, F., Bingen, C., Kyrola, E., Tamminen, J., Sofieva, V. F., Hassinen, S., Seppala, A., Verronen, P., Bertaux, J.-L., Hauchecorne, A., Dalaudier, F., D’Andon, O. F., Barrot, G., Mangin, A., Theodore, B., Guirlet, M., Renard, J. B., Fraisse, R., Snoeij, P., Koopman, R., and Saavedra, L.: GOMOS serendipitous data products: The mesospheric sodium layer and various limb emissions, Adv. Space Res., 36, 967-972, 2005.

Fussen, D., Vanhellemont, F., Tétard, C., Mateshvili, N., Dekemper, E., Loodts, N., Bingen, C., Kyrölä, E., Tamminen, J., Sofieva, V., Hauchecorne, A., Dalaudier, F., Bertaux, J.-L., Barrot, G., Blanot, L., Fanton d'Andon, O., Fehr, T., Saavedra, L., Yuan, T., and She, C.-Y.: A global climatology of the mesospheric sodium layer from GOMOS data during the 2002-2008 period, Atmos. Chem. Phys., 10, 9225-9236, doi:10.5194/acp-10-92252010, 2010.

Gettelman, A., Hegglin, M. I., Son, S.-W., Kim, J., Fujiwara, M., Birner, T., Kremser, S., Rex, M., Añel, J. A., Akiyoshi, H., Austin, J., Bekki, S., Braesike, P., Brühl, C., Butchart, N., Chipperfield, M., Dameris, M., Dhomse, S., Garny, H., Hardiman, S. C., Jöckel, P., Kinnison, D. E., Lamarque, J. F., Mancini, E., Marchand, M., Michou, M., Morgenstern, O., Pawson, S., Pitari,
G., Plummer, D., Pyle, J. A., Rozanov, E., Scinocca, J., Shepherd, T. G., Shibata, K., Smale, D., Teyssèdre, H., and Tian, W.: Multimodel assessment of the upper troposphere and lower stratosphere: Tropics and global trends, J. Geophys. Res.-Atmos., 115, D00M08, doi:10.1029/2009JD013638, 2010.

Gettelman, A., Hoor, P., Pan, L. L., Randel, W. J., Hegglin, M. I., and Birner, T.: The extratropical upper troposphere and lower stratosphere, Rev. Geophys., 49, RG3003, doi:10.1029/2011RG000355, 2011.

Hakkarainen, J., Laine, M., and Tamminen, J.: GOMOS one-step retrieval algorithm, Proc. SPIE., 8890, 88900, doi:10.1117/12.2027109, 2013.

Hegglin, M. I., Gettelman, A., Hoor, P., Krichevsky, R., Manney, G. L., Pan, L. L., Son, S.-W., Stiller, G., Tilmes, S., Walker, K. A., Eyring, V., Shepherd, T. G., Waugh, D., Akiyoshi, H., Añel, J. A., Austin, J., Baumgaertner, A., Bekki, S., Braesicke, P., Brühl, C., Butchart, N., Chipperfield, M., Dameris, M., Dhomse, S., Frith, S., Garny, H., Hardiman, S. C., Jöckel, P., Kinnison, D. E., Lamarque, J. F., Mancini, E., Michou, M., Morgenstern, O., Nakamura, T., Olivié, D., Pawson, S., Pitari, G., Plummer, D. A., Pyle, J. A., Rozanov, E., Scinocca, J. F., Shibata, K., Smale, D., Teyssèdre, H., Tian, W., and Yamashita, Y.: Multimodel assessment of the upper troposphere and lower stratosphere: Extratropics, J. Geophys. Res.-Atmos., 115, D00M09, doi:10.1029/2010JD013884, 2010.

Hubert, D., Lambert, J.-C., Verhoelst, T., Granville, J., Keppens, A., Baray, J.-L., Bourassa, A. E., Cortesi, U., Degenstein, D. A., Froidevaux, L., Godin-Beekmann, S., Hoppel, K. W., Johnson, B. J., Kyrölä, E., Leblanc, T., Lichtenberg, G., Marchand, M., McElroy, C. T., Murtagh, D., Nakane, H., Portafaix, T., Querel, R., Russell III, J. M., Salvador, J., Smit, H. G. J., Stebel, K., Steinbrecht, W., Strawbridge, K. B., Stübi, R., Swart, D. P. J., Taha, G., Tarasick, D. W., Thompson, A. M., Urban, J., van Gijsel, J. A. E., Van Malderen, R., von der Gathen, P., Walker, K. A., Wolfram, E., and Zawodny, J. M.: Ground-based assessment of the bias and long-term stability of $14 \mathrm{limb}$ and occultation ozone profile data records, Atmos. Meas. Tech., 9, 2497-2534, doi:10.5194/amt-9-2497-2016, 2016.

Kunze, M., Braesicke, P., Langematz, U., Stiller, G., Bekki, S., Brühl, C., Chipperfield, M., Dameris, M., Garcia, R., and Giorgetta, M.: Influences of the Indian Summer Monsoon on Water Vapor and Ozone Concentrations in the UTLS as Simulated by Chemistry-Climate Models, J. Climate, 23, 3525-3544, doi:10.1175/2010JCLI3280.1, 2010.

Kyrölä, E., Tamminen, J., Leppelmeier, G. W., Sofieva, V. F., Hassinen, S., Bertaux, J.-L., Hauchecorne, A., Dalaudier, F., Cot, C., Korablev, O., Fanton D’Andon, O., Barrot, G., Mangin, A., Theodore, B., Guirlet, M., Etanchaud, F., Snoij, P., Koopman, R., Saavedra, L., Fraisse, R., Fussen, D., and Vanhellemont, F.: GOMOS on Envisat: An overview, Adv. Space Res., 33, 1020-1028, 2004.

Kyrölä, E., Tamminen, J., Sofieva, V., Bertaux, J. L., Hauchecorne, A., Dalaudier, F., Fussen, D., Vanhellemont, F., Fanton d'Andon, O., Barrot, G., Guirlet, M., Mangin, A., Blanot, L., Fehr, T., Saavedra de Miguel, L., and Fraisse, R.: Retrieval of atmospheric parameters from GOMOS data, Atmos. Chem. Phys., 10, 1188111903, doi:10.5194/acp-10-11881-2010, 2010.

Laeng, A., Grabowski, U., von Clarmann, T., Stiller, G., Glatthor, N., Höpfner, M., Kellmann, S., Kiefer, M., Linden, A., Lossow, 
S., Sofieva, V., Petropavlovskikh, I., Hubert, D., Bathgate, T., Bernath, P., Boone, C. D., Clerbaux, C., Coheur, P., Damadeo, R., Degenstein, D., Frith, S., Froidevaux, L., Gille, J., Hoppel, K., McHugh, M., Kasai, Y., Lumpe, J., Rahpoe, N., Toon, G., Sano, T., Suzuki, M., Tamminen, J., Urban, J., Walker, K., Weber, M., and Zawodny, J.: Validation of MIPAS IMK/IAA V5R_O3_224 ozone profiles, Atmos. Meas. Tech., 7, 39713987, doi:10.5194/amt-7-3971-2014, 2014.

Liu, C., Liu, Y., Cai, Z., Gao, S., Lü, D., and Kyrölä, E.: A MaddenJulian Oscillation-triggered record ozone minimum over the Tibetan Plateau in December 2003 and its association with stratospheric "low-ozone pockets", Geophys. Res. Lett., 36. L15830, doi:10.1029/2009GL039025, 2009.

Manney, G. L., Hegglin, M. I., Daffer, W. H., Santee, M. L., Ray, E. A., Pawson, S., Schwartz, M. J., Boone, C. D., Froidevaux, L., Livesey, N. J., Read, W. G., and Walker, K. A.: Jet characterization in the upper troposphere/lower stratosphere (UTLS): applications to climatology and transport studies, Atmos. Chem. Phys., 11, 6115-6137, doi:10.5194/acp-11-6115-2011, 2011.

Meijer, Y. J., Swart, D. P. J., Allaart, M., Andersen, S. B., Bodeker, G., Boyd, Braathena, G., Calisesia, Y., Claude, H., Dorokhov, V., von der Gathen, P., Gil, M., Godin-Beekmann, S., Goutail, F., Hansen, G., Karpetchko, A., Keckhut, P., Kelder, H. M., Koelemeijer, R., Kois, B., Koopman, R. M., Lambert, J.-C., Leblanc, T., McDermid, I. S., Pal, S., Kopp, G., Schets, H., Stubi, R., Suortti, T., Visconti, G., and Yela, M.: Pole-to-pole validation of ENVISAT/GOMOS ozone profiles using data from groundbased and balloon-sonde measurements, J. Geophys. Res., 109, D23305, doi:10.1029/2004JD004834, 2004.

Mze, N., Hauchecorne, A., Bencherif, H., Dalaudier, F., and Bertaux, J.-L.: Climatology and comparison of ozone from ENVISAT/GOMOS and SHADOZ/balloon-sonde observations in the southern tropics, Atmos. Chem. Phys., 10, 8025-8035, doi:10.5194/acp-10-8025-2010, 2010.

Park, M., Randel, W. J., Gettelman, A., Massie, S. T., and Jiang, J. H.: Transport above the Asian summer monsoon anticyclone inferred from Aura Microwave Limb Sounder tracers, J. Geophys. Res.-Atmos., 112, D16309, doi:10.1029/2006JD008294, 2007.

Rahpoe, N., Weber, M., Rozanov, A. V., Weigel, K., Bovensmann, H., Burrows, J. P., Laeng, A., Stiller, G., von Clarmann, T., Kyrölä, E., Sofieva, V. F., Tamminen, J., Walker, K., Degenstein, D., Bourassa, A. E., Hargreaves, R., Bernath, P., Urban, J., and Murtagh, D. P.: Relative drifts and biases between six ozone limb satellite measurements from the last decade, Atmos. Meas. Tech., 8, 4369-4381, doi:10.5194/amt-8-4369-2015, 2015.

Randel, W. J. and Jensen, E. J.: Physical processes in the tropical tropopause layer and their roles in a changing climate, Nat. Geosci., 6, 169-176, doi:10.1038/ngeo1733, 2013.

Sioris, C. E., McLinden, C. A., Fioletov, V. E., Adams, C., Zawodny, J. M., Bourassa, A. E., Roth, C. Z., and Degenstein, D. A.: Trend and variability in ozone in the tropical lower stratosphere over 2.5 solar cycles observed by SAGE II and OSIRIS, Atmos. Chem. Phys., 14, 3479-3496, doi:10.5194/acp-14-34792014, 2014.

Sofieva, V. F., Tamminen, J., Haario, H., Kyrölä, E., and Lehtinen, M.: Ozone profile smoothness as a priori information in the inversion of limb measurements, Ann. Geophys., 22, 3411-3420, doi:10.5194/angeo-22-3411-2004, 2004.
Sofieva, V. F., Kan, V., Dalaudier, F., Kyrölä, E., Tamminen, J., Bertaux, J.-L., Hauchecorne, A., Fussen, D., and Vanhellemont, F.: Influence of scintillation on quality of ozone monitoring by GOMOS, Atmos. Chem. Phys., 9, 9197-9207, doi:10.5194/acp9-9197-2009, 2009.

Sofieva, V. F., Vira, J., Kyrölä, E., Tamminen, J., Kan, V., Dalaudier, F., Hauchecorne, A., Bertaux, J.-L., Fussen, D., Vanhellemont, F., Barrot, G., and Fanton d'Andon, O.: Retrievals from GOMOS stellar occultation measurements using characterization of modeling errors, Atmos. Meas. Tech., 3, 1019-1027, doi:10.5194/amt-3-1019-2010, 2010.

Sofieva, V. F., Rahpoe, N., Tamminen, J., Kyrölä, E., Kalakoski, N., Weber, M., Rozanov, A., von Savigny, C., Laeng, A., von Clarmann, T., Stiller, G., Lossow, S., Degenstein, D., Bourassa, A., Adams, C., Roth, C., Lloyd, N., Bernath, P., Hargreaves, R. J., Urban, J., Murtagh, D., Hauchecorne, A., Dalaudier, F., van Roozendael, M., Kalb, N., and Zehner, C.: Harmonized dataset of ozone profiles from satellite limb and occultation measurements, Earth Syst. Sci. Data, 5, 349-363, doi:10.5194/essd-5-349-2013, 2013.

Sofieva, V. F., Tamminen, J., Kyrölä, E., Laeng, A., von Clarmann, T., Dalaudier, F., Hauchecorne, A., Bertaux, J.-L., Barrot, G., Blanot, L., Fussen, D., and Vanhellemont, F.: Validation of GOMOS ozone precision estimates in the stratosphere, Atmos. Meas. Tech., 7, 2147-2158, doi:10.5194/amt-7-2147-2014, 2014a.

Sofieva, V. F., Tamminen, J., Kyrölä, E., Mielonen, T., Veefkind, P., Hassler, B., and Bodeker, G. E.: A novel tropopause-related climatology of ozone profiles, Atmos. Chem. Phys., 14, 283-299, doi:10.5194/acp-14-283-2014, 2014b.

Tamminen, J., Kyrölä, E., and Sofieva, V. F.: Does prior information improve measurements?, in: Occultations for Probing Atmosphere and Climate - Science from the OPAC-1 Workshop, edited by: Kirchengast, G., Foelsche, U., and Steiner, A. K., 8798, Springer Verlag, Berlin Heidelberg, Germany, 2004.

Tamminen, J., Karhu, J. A., Kyrölä, E., Hassinen, S., Kyrö, E., Karpechko, A. Y., and Piacentini, E.: GOMOS Ozone Profiles at High Latitudes: Comparison with Marambio and Sodankylä Sonde Measurements, in: Atmosphere and Climate SE - 5, edited by: Foelsche, U., Kirchengast, G., and Steiner, A., 47-54, Springer Berlin Heidelberg, Germany, 2006.

Tamminen, J., Kyrölä, E., Sofieva, V. F., Laine, M., Bertaux, J.-L., Hauchecorne, A., Dalaudier, F., Fussen, D., Vanhellemont, F., Fanton-d'Andon, O., Barrot, G., Mangin, A., Guirlet, M., Blanot, L., Fehr, T., Saavedra de Miguel, L., and Fraisse, R.: GOMOS data characterisation and error estimation, Atmos. Chem. Phys., 10, 9505-9519, doi:10.5194/acp-10-9505-2010, 2010.

Tétard, C., Fussen, D., Bingen, C., Capouillez, N., Dekemper, E., Loodts, N., Mateshvili, N., Vanhellemont, F., Kyrölä, E., Tamminen, J., Sofieva, V., Hauchecorne, A., Dalaudier, F., Bertaux, J.-L., Fanton d'Andon, O., Barrot, G., Guirlet, M., Fehr, T., and Saavedra, L.: Simultaneous measurements of $\mathrm{OClO}, \mathrm{NO}_{2}$ and $\mathrm{O}_{3}$ in the Arctic polar vortex by the GOMOS instrument, Atmos. Chem. Phys., 9, 7857-7866, doi:10.5194/acp-9-7857-2009, 2009.

Thompson, A. M., Miller, S. K., Tilmes, S., Kollonige, D. W., Witte, J. C., Oltmans, S. J., Johnson, B. J., Fujiwara, M., Schmidlin, F. J., Coetzee, G. J. R., Komala, N., Maata, M., bt Mohamad, M., Nguyo, J., Mutai, C., Ogino, S.-Y., Da Silva, F. R., Leme, N. 
M. P., Posny, F., Scheele, R., Selkirk, H. B., Shiotani, M., Stübi, R., Levrat, G., Calpini, B., Thouret, V., Tsuruta, H., Canossa, J. V., Vömel, H., Yonemura, S., Diaz, J. A., Tan Thanh, N. T., and Thuy Ha, H. T.: Southern Hemisphere Additional Ozonesondes (SHADOZ) ozone climatology (2005-2009): Tropospheric and tropical tropopause layer (TTL) profiles with comparisons to OMI-based ozone products, J. Geophys. Res.-Atmos., 117, D23301, doi:10.1029/2011JD016911, 2012.

van Gijsel, J. A. E., Swart, D. P. J., Baray, J.-L., Bencherif, H., Claude, H., Fehr, T., Godin-Beekmann, S., Hansen, G. H., Keckhut, P., Leblanc, T., McDermid, I. S., Meijer, Y. J., Nakane, H., Quel, E. J., Stebel, K., Steinbrecht, W., Strawbridge, K. B., Tatarov, B. I., and Wolfram, E. A.: GOMOS ozone profile validation using ground-based and balloon sonde measurements, Atmos. Chem. Phys., 10, 10473-10488, doi:10.5194/acp10-10473-2010, 2010.

Vanhellemont, F., Fussen, D., Bingen, C., Kyrölä, E., Tamminen, J., Sofieva, V. F., Hassinen, S., Bertaux, J.-L., Hauchecorne, A., Dalaudier, F., D’Andon, O. F., Barrot, G., Mangin, A., Theodore, B., Guirlet, M., Renard, J. B., Fraisse, R., Snoeij, P., Koopman, R., and Saavedra, L.: A first comparison of GOMOS aerosol extinction retrievals with other measurements, Adv. Space Res., 36, 894-898, 2005.

Vanhellemont, F., Fussen, D., Mateshvili, N., Tétard, C., Bingen, C., Dekemper, E., Loodts, N., Kyrölä, E., Sofieva, V., Tamminen, J., Hauchecorne, A., Bertaux, J.-L., Dalaudier, F., Blanot, L., Fanton d'Andon, O., Barrot, G., Guirlet, M., Fehr, T., and Saavedra, L.: Optical extinction by upper tropospheric/stratospheric aerosols and clouds: GOMOS observations for the period 20022008, Atmos. Chem. Phys., 10, 7997-8009, doi:10.5194/acp-107997-2010, 2010. von Clarmann, T., Glatthor, N., Grabowski, U., Höpfner, M., Kellmann, S., Kiefer, M., Linden, A., Tsidu, G. M., Milz, M., Steck, T., Stiller, G. P., Wang, D. Y., Fischer, H., Funke, B., GilLópez, S., López-Puertas, M., Mengistu Tsidu, G., Milz, M., Steck, T., Stiller, G. P., Wang, D. Y., Fischer, H., Funke, B., Gil-López, S., and López-Puertas, M.: Retrieval of temperature and tangent altitude pointing from limb emission spectra recorded from space by the Michelson Interferometer for Passive Atmospheric Sounding (MIPAS), J. Geophys. Res., 108, 4736, doi:10.1029/2003JD003602, 2003.

von Clarmann, T., Glatthor, N., Koukouli, M. E., Stiller, G. P., Funke, B., Grabowski, U., Höpfner, M., Kellmann, S., Linden, A., Milz, M., Steck, T., and Fischer, H.: MIPAS measurements of upper tropospheric $\mathrm{C}_{2} \mathrm{H}_{6}$ and $\mathrm{O}_{3}$ during the southern hemispheric biomass burning season in 2003, Atmos. Chem. Phys., 7, 5861-5872, doi:10.5194/acp-7-5861-2007, 2007.

von Clarmann, T., Höpfner, M., Kellmann, S., Linden, A., Chauhan, S., Funke, B., Grabowski, U., Glatthor, N., Kiefer, M., Schieferdecker, T., Stiller, G. P., and Versick, S.: Retrieval of temperature, $\mathrm{H}_{2} \mathrm{O}, \mathrm{O}_{3}, \mathrm{HNO}_{3}, \mathrm{CH}_{4}, \mathrm{~N}_{2} \mathrm{O}, \mathrm{ClONO}_{2}$ and $\mathrm{ClO}$ from MIPAS reduced resolution nominal mode limb emission measurements, Atmos. Meas. Tech., 2, 159-175, doi:10.5194/amt-2-159-2009, 2009.

WMO: Meteorology - A three-dimensional science: Second session of the Commission for Aerology, WMO Bull., IV, 134-138, 1957. 